Josef Eskhult*

\title{
Vulgar Latin as an emergent concept in the Italian Renaissance (1435-1601): its ancient and medieval prehistory and its emergence and development in Renaissance linguistic thought
}

https://doi.org/10.1515/joll-2018-0006

Abstract: This article explores the formation of Vulgar Latin as a metalinguistic concept in the Italian Renaissance (1435-1601) considering its continued, although criticized, use as a concept and term in modern Romance and Latin linguistics (1826 until the present). The choice of this topic is justified in view of the divergent previous modern historiography and because of the lack of a coherent historical investigation. The present study is based on a broad selection of primary sources, in particular from classical antiquity and the Italian Renaissance.

Firstly, this article traces and clarifies the prehistory of the concept of Vulgar Latin in ancient and medieval linguistic thought. Section 2 demonstrates that the concept of Vulgar Latin as a low social variety does not exist in pre-Renaissance linguistic thought.

Secondly, this article describes and analyzes how, why and when the concept of Vulgar Latin emerged and developed in the linguistic thought of the Italian Renaissance. Section 3 surveys the historical intellectual contexts of the debates in which this concept was formed, namely questione della lingua in the Latin and Vernacular Italian Renaissances. Section 4 demonstrates how the ancient concept and term of sermo vulgaris as a diaphasic variety was revived, but also modified, in the Latin Renaissance of the fifteenth century, when the leading humanists developed new ideas on the history, nature and variability of ancient Latin. Section 5 demonstrates how a diglossic concept of Vulgar Latin was formed in the vernacular Italian Renaissance of the sixteenth century, when Italian philologists more carefully approached the topic of the historical origin and emergence of Italian.

Thirdly, Section 6 presents a synthesis of the historiographical results that are attained and revises modern historiography on some important points.

\footnotetext{
*Corresponding author: Josef Eskhult, Department of Linguistics and Philology, Uppsala University, Thunbergsvägen 3 H, Box 635, 75126 Uppsala, Sweden,

E-mail: Josef.Eskhult@lingfil.uu.se
}

Ә Open Access. (c) 2018 Eskhult, published by De Gruyter. (cc) BY-NC-ND This work is licensed under the Creative Commons Attribution-NonCommercial-NoDerivatives 4.0 License. 
Keywords: Ancient Latin, Vulgar Latin, literary Latin, sermo vulgaris, diaphasic variety, low variety, diglossia, Italian Renaissance, Cicero, Bruni, Biondo, Poggio, Valla, Castelvetro, Cittadini

\section{Introduction}

\subsection{Vulgar Latin as a criticized modern term}

In modern Romance and Latin linguistics, the term Vulgar Latin is in regular, widespread use as a technical term. Nonetheless, its adequacy as an analytical tool is controversial for several reasons; its origin in pre-modern and "prescientific" linguistic thought, its general mismatch with the ancient designation sermo vulgaris, its vagueness due to its different definitions, its lack of appropriateness due to its associability with "vulgar" in a pejorative sense ('mean, coarse'), and its reification or hypostatization into a real and identifiable distinct and uniform linguistic entity in contradistinction to standard Latin. ${ }^{1}$ For these reasons, several leading scholars avoid the term or use it within quotation marks. This article does not evaluate the validity of this criticism, but presents a historiographical study of how and why Vulgar Latin emerged and developed as a concept and as a term. The present survey does however provide a historical key for resolving some lingering conceptual complexities related to the term as used in modern research.

\subsection{Hypotheses and general purposes}

This article distinguishes between "concept" and "term" according to the semiotic triangle. A concept is a complex set of thoughts or abstractions about a given object, real or presumed, and a concept can be confirmed and made available by a term. ${ }^{2}$ As an emergent pre-modern concept, Vulgar Latin comprised a set of ideas concerning the linguistic situation of the Latin speech community in antiquity. These ideas shifted in relation to various conceptual parameters that were applied. This article posits three hypotheses concerning the emergence of Vulgar Latin as a concept:

1 This is my systematization of the criticism raised by Lloyd (1979: 111-120). On the danger of hypostatization of the term "Vulgar Latin," see Adams (2013: 5).

2 For the distinction concept versus term as applied to conceptual linguistic historiography, see Haßler and Neis (2009: 81-84). 
1. It aimed at conceptualizing either the variability of ancient Latin $^{3}$ from a synchronic-diaphasic perspective or a distinct low variety ${ }^{4}$ of ancient Latin as the source of individual Romance languages from a diachronic and diastratic perspective.

2. As a concept, it emerged as a product of Renaissance linguistic reflection on two different but interrelated topics; the identity, nature, and variability of the language spoken in ancient Rome, and the historical origin of Italian.

3. Only as a diachronic and diglossic concept was it provided with a certain terminology. As a synchronic and diaphasic concept, it was hardly terminized.

This article also has three general purposes, namely:

- to clarify the ancient and medieval prehistory of the concept of Vulgar Latin;

- to describe and analyze the emergence and development of a shifting concept of Vulgar Latin in the Italian Renaissance with special regard for its sense of being a distinct low variety;

- to revise the extant historiography on the emergence of the diglossic concept of Vulgar Latin, in particular the tradition that traces this concept back to Bruni (1435).

3 The term Ancient Latin is used to refer to "Latin of all antiquity" in general (ca. 600 BC-600 $\mathrm{AD}$ ) and thus is not to be confused with the terms Archaic Latin (ca. 600-240 BC) or Old Latin (ca. $240 \mathrm{BC}-80 \mathrm{BC}$ ).

4 In this article the concept of Vulgar Latin as a low variety will be referred to as the diglossic concept of Vulgar Latin. The term diglossia is certainly an ambiguous and disputed modern sociolinguistic term, but in this article it is used in the original sense in which the sociolinguist Charles Ferguson introduced it to modern linguistics in his seminal article, where the diglossic situation is defined as "a relatively stable language situation in which, in addition to the primary dialects of the language (which may include a standard or regional standards), there is a very divergent, highly codified (often grammatically more complex) superposed variety, the vehicle of a large and respectful body of written literature, either in an earlier period or in another speech community, which is learned largely by formal education and is used for most written and formal spoken purposes, but is not used by any sector of the community for ordinary conversation" (Ferguson 1959: 336). In general, Ferguson applied a genealogical perspective to diglossia and thus considered it a monolingual phenomenon - i.e. as occurring within the limits of one single language, with the high and low varieties as historically cognate - rather than referring to a bilingual or multilingual situation through the application of a typological perspective (Kremnitz 2004 [1987]: 159-160). He analyzed diglossia by nine criteria: (i) function of written and spoken communication, viz. the difference of communicative functions between the high and low variety, (ii) prestige, (iii) literary heritage, (iv) method of acquisition, (v) degree of standardization, (vi) stability, (vii) grammar, (viii) lexicon, and (ix) phonology. 


\subsection{Research questions}

This article poses the following research questions:

1. Why is the concept of Vulgar Latin as a distinct low social variety of ancient Latin not attested in the theorizing of antiquity and the Middle Ages?

2. How, why and when did Vulgar Latin emerge and develop as a concept in the Italian Renaissance?

3. How, why and when was a concept of Vulgar Latin in its different senses terminized in the Renaissance and early modern period?

\subsection{Sources}

In answering the first research question, this article analyzes ancient and medieval linguistic theorists of great significance (the author of Rhet. ad Her., Cicero, Quintilian, Augustine, and Dante). In answering the other two research questions, it explores primary sources by theorists who were key theorists and whose importance is generally acknowledged in previous research (Bruni, Biondo, Castelvetro, and Cittadini), and by theorists qualifying as important, but who are not given as much attention in previous research on the conceptual history of Vulgar Latin (Poggio, Filelfo, Guarino, Valla, and Barrius). ${ }^{5}$

\subsection{Previous research}

The conceptual history of Vulgar Latin from the Renaissance to the present day has hitherto not been written. ${ }^{6}$ From Fuchs (1849: 28-30) to the recent contributions by Lüdtke (2005: 34-39), Coseriu and Meisterfeld (2003) and Schöntag (2017: 111-129), Romance linguists have tried to trace the emergence of the concept of Vulgar Latin as a low variety. The various positions may by classified as follows:

1. The concept of Vulgar Latin as a low variety is not to be found in any Italian or French linguist of the fifteenth and sixteenth centuries (Strauss 1938: 125).

2. The concept is indicated by Dante or traceable to Dante (Coseriu and Meisterfeld 2003: 132, 158; Meier 1941: 6; Lüdtke 2005: 31 and 35).

3. The concept is first attested in Leonardo Bruni 1435 (Fuchs 1849: 30; Schuchardt 1866: 44; Holmes 1928: 52-53; Ettmayer 1916: 231; Manczak 1995: 29-30; Müller 2001: 13-14).

5 All translations of primary sources from Latin into English in this article are mine.

6 Kiesler: “Die Begriffsgeschichte des 'Vulgärlateins' ist noch zu schreiben” (Kiesler 2006: 8). 
4. The concept is first attested in Biondo 1435 (Coseriu and Meisterfeld 2003: 154-158).

5. The concept is first attested in Tolomei 1555 (Tavoni 1998: 48).

6. The concept is first attested in Castelvetro 1572 (Trabalza 1908: 171; Faithfull 1953: 286; Melzi 1966: 162-169; Marazzini 1993a: 72-73, 1999: 194-195; Lüdtke 2001: 13).

7. The concept is either (a) first attested in Celso Cittadini 1601 (e.g. Vannini 1920; Vitale 1955: 44; Coseriu 2008: 108; Geckeler and Wolf 2012 [1995]: 171; Schöntag 2017: 125) or (b) in relation to Tolomei and Castelvetro first refined by Cittadini (Faithfull 1962: 247-249; Marazzini 1993a: 196-197, 1999: 74-75; Lüdtke 2001: 17).

8. The concept is first attested in Bonamy 1756 (e.g. Müller-Lancé 2006: 58).

9. The concept cannot be exactly dated, but arose roughly in the sixteenth to eighteenth centuries (Lloyd 1979: 111-112).

\section{Ancient and medieval prehistory}

\subsection{Sermo vulgaris in Roman metalinguistic reflection}

In Renaissance, early modern, and modern linguistic thought, sermo vulgaris and similar designations formed on the stem vulg- have often been regarded as evidence of a distinct low social variety of ancient Latin. Such an interpretation lacks support in Roman metalinguistic thought about these kinds of designations. In linguistic and non-linguistic contexts, the adjective vulgaris primarily means 'belonging to common people, common, usual, ordinary' (OLD s.v. vulgaris 1 and 3) and is sometimes juxtaposed with communis, popularis, pervagatus (Lewis and Short, s.v. vulgaris) or with usitatus, or opposed to singularis (Calboli 1994: 35). As an adjective, it does not necessarily refer to the lower social orders or classes. In all occurrences, the designation sermo vulgaris evidently refers to ordinary language as opposed to elaborate or refined language. ${ }^{7}$ Ordinary language may refer to either non-rhetorical speech as opposed to speech formed according to the art of rhetoric (Rhet. ad Her. IV, 56, 69 ${ }^{8}$; and

7 Calboli (1994: 34-35) more cautiously proposes this as a possible distinction, and argues that Vulgar Latin in the additional sense of rough and incorrect language is supported by the ancient conception of sermo rusticus.

8 In ancient Latin literature, this is the first record of the designation sermo vulgaris. The public speaker is here instructed to use a style marked by impressiveness (gravitas), distinction 
Quintilian, Inst. orat. 12, 10, 43) or non-technical speech as opposed to usage formed according to the art of dialectics (Cicero, Acad. 1, 5). ${ }^{9}$

Quintilian (Inst. orat. 12, 10, 40-43) identifies colloquial language, sermo cotidianus, with sermo vulgaris, and opposes it to rhetorical language. In doing so, he distinguishes these forms of language on the basis of their different communicative functions. He attributes a referential (denotative, informative, declarative) function to sermo vulgaris, and an efficient (persuasive, expressive, appellative) function to rhetorical language. ${ }^{10}$ Adams (2013: 20) interprets Quint., Inst. orat. 12, 10, 40-43 as differentiating between casual and careful speech.

As a particular case of the opposition ordinary versus elaborate, Cicero (Orat. 195) once refers to the speech of common people, sermo vulgi, as devoid of rhythm (extra numerum and nimis dissolutum, ut pervagatum ac vulgare videatur) in opposition to poetry (numerosa) and to oratory, which is an intermediate type with some rhythmical features (e.g. clausulae).

As a linguistic term, vulgaris has in general a neutral sense. In Cicero (Acad. $1,5)$ it is once used about non-technical usage, as was remarked above. ${ }^{11}$ In classical rhetorical theory it is neutral and closely associated with the plain style. The author of Rhetorica ad Herennium $(4,8,11)$ describes the plain style (adtenuata figura) as participating (with the grand and middle styles) in the quality of faultless speech (oratio non vitiosa) and as 'adapting itself to the common usage of correct speech' (demissa usque ad usitatissimam puri consuetudinem sermonis). Thus, he includes the plain style in the norms of correct

(dignitas), and euphony (suavitas), in brief, to speak in a rhetorical style (oratorie loqui), and not to express the naked and unadorned topic in a commonplace language (vulgari sermone).

9 In the context (Cic., Acad. 1, 5), Cicero himself indicates that sermo vulgaris is marked by a lack of definitions, divisions, partitions, and conclusions (nulla arte adhibita ... nihil definiunt, nihil partiuntur ... nihil concludunt), because such features are the characteristics of discourse formed by the art of rhetoric and dialectics (ars dicendi et disserendi). Seppänen (2014: 123-124) proposes such an interpretation of the sense of sermo vulgaris here.

10 In Quint., Inst. orat. 2, 13, 11 (vulgaris consuetudo), 8, 6, 20 (cotidiani sermonis usus), 9, 1, 4 (communis ratio), 9, 1, 9 (vulgaris et simplex oratio), 11, 3, 3 (cotidianus et semper eodem modo formatus sermo, and vulgare dicendi genus) 11, 3, 5 (vulgaris usus), Quintilian consistently makes a functionalist distinction between ordinary usage and rhetorical speech (orationis ornatus) in the actual use or relative frequency of tropes and figures of speech. Likewise, in Quint., Inst. orat. $2,10,13$, the common pronunciation of words (ut nos vulgo loquimur, communis sermo) is equated with artlessness (sine arte) and contrasted to the refined articulation of comedy actors. 11 The reference to sermo vulgaris in Cic., Acad. 1, 5 is often mistakenly considered a reference to a social low variety with negative, derogatory semantic implications (so Müller 2001: 159), while Herman (2000) apparently takes it as a stylistic (diaphasic) variety in the sense of "a language with no rhetorical adornments" (Herman 2000: 7). 
Latin. In another passage (Rhet. Her. 4, 10, 14), he equates the plain style (adtenuatum genus) with the lowest and everyday (infimus et cotidianus sermo) and exemplifies it in a well-known passage. ${ }^{12}$

Cicero (Orator 76) describes the plain style, genus humile, tenue, summissum, or abiectum, as 'imitating usage' (consuetudinem imitans), which is explained as lacking rhythm, periodic structure, and rhetorical ornamentation (Cic., Orat. 7778), but still being fully capable of expressing pure and correct Latin (sermo purus et Latinus) and achieving clarity (dilucide planeque, Cic., Orat. 79). This plain style (humilis et abiecta oratio) is once identified with sermo vulgaris (Cic., Orat. 192) and once called genus vulgare dicendi (Brutus 302). In public speaking, Cicero (De orat. 1, 12) considers it a great fault to deviate from popular speech (vulgare genus orationis), which he equates with common usage (consuetudo). Cicero (Epist. 9, 21, 1) once uses sermo plebeius as a term of a colloquial epistolary style, explained as being composed of everyday words (quotidianis verbis), when responding to his addressee's annoyance at Cicero's use of tropes (verborum fulmina, otherwise termed splendor verborum) in his letters. Thus, the term does not refer to a social variety, but is only occasioned by Cicero's contention that not all the Papirii were of plebeian origin (cf. Burton 2009: 55).

In ancient linguistic commentators and grammarians, single forms, words, and phrases are referred to as vulgarisms (vulgo dicitur) to mark them as nonstandard or sub-standard Latin (cf. Müller 2001: 142-155). Gellius comments on meanings, forms, and words in common usage (vulgo dicitur, vulgus dicit, in sermonibus vulgi) to mark them negatively or to oppose them to correct Latin (Gell., Noct. Att. 13, 6, 3 pure atque integre). He remarks that some authors do not use certain words in senses typical of common and popular usage (Gell., Noct. Att. 3, 16, 18 non vulgariae significationis; Gell., Noct. Att. 9, 1, 8 non ex vulgari consuetudine), but instead in agreement with correct Latin (Gell., Noct. Att. 9, 1, 8 proprie et latine).

In commenting on the popular word ossum 'bone' for standard Latin os (with short vowel), Augustine certainly sets up a conceptual opposition between popular usage, loquendi consuetudo vulgaris, and literary correctness, integritas litterata (August., De doct. Chr. III, 3, 43). This passage is to be interpreted in the context of the opposition between incorrect and correct Latin in single forms or words. Even so, it testifies to the increasing phonological and lexical divergence between standard classical Latin and the popular and common use of Latin,

12 Calboli (1994: 28-34) calls renewed attention to this passage from a text-critical and linguistic perspective with observations of anticipations of Romance features. It is beyond the scope of the present article to evaluate the actual variation of ancient Latin and its relation to the plain style. 
which Augustine in a letter refers to as latina consuetudo popularis (August., Ep. 149, 2, 27), quotidianus usus and usitatus loquendi modus (August., Ep. 149, 2, 14).

\subsection{Latina lingua and Romana lingua as ancient binomial terms}

The ancient binomial terminology of Latin had a strong impact on medieval terminology of the Romance languages and thus on Renaissance conceptualizations of Vulgar Latin. The terms are Latina lingua (or the like, e.g. latinus sermo) and Romana lingua (similarly with variants). As glottonyms, these terms are used as normal and unmarked designations to mark a contrast to other languages (i.e. they have a crosslinguistic contrastive function).

In addition to this use, each term has a specific use of its own. Latina lingua may also refer to correct Latin, i.e. linguistic correctness in Latin (latinitas, sermo latinus, latine loqui), and Romana lingua may in grammatical discourse, namely in the definition of latinitas, refer to the geographical variety of the city of Rome, in contrast to other local or regional varieties.

\subsection{Latin and the vernacular in medieval linguistic theory}

In the Middle Ages, a terminological distinction between Latin and the Romance vernaculars was developed. In Romance-speaking areas except for Italy, the vernacular was referred to by derivatives of Romanicus ('romans, romanz, romançe, romance, romancio', Kramer 1998: 149-160) or Romanus ('romana, roman, romano'). In Italy, volgare was regularly used to refer to the vernacular in contrast to Latin (Kramer 1998: 102). ${ }^{13}$

At the same time, there is also a certain amount of terminological indiscrimination in the Middle Ages. Many Romance vernaculars were referred to by derivatives of Latinus, either in inherited words or in learned loanwords (Kramer 1998: 107-128). In Italy, this term was generally avoided as a linguistic designation (Kramer 1998: 100-101), but in a few cases it is used in combination with the common term for the vernacular. Dante designates his ideal standard of Italian (vulgare illustre, cardinale, aulicum et curiale) as vulgare latium or latium vulgare (Dante, De vulgari eloquentia 1, 10; 1, 19). Boccaccio uses the term latino

13 The first certain record is from $999 \mathrm{AD}$ in the epitaph of Pope Gregory, lines 11-12 Usus francisca, vulgari et voce latina / instituit populos eloquio triplici (cf. Clackson and Horrocks 2007: 266-267). A later instance is Dante, Conv. 1, 6, 8: volgare italico. 
vulgare (Teseida, preface) to refer to contemporary literary Italian. These multiword terms are consequently not attestations of the concept of Vulgar Latin.

Furthermore, a qualitative dichotomy between Latin and the vernacular emerged in the high and late Middle Ages, when linguistic thinking in the areas of grammar and logic underwent a period of innovation (Bursill-Hall 1995: 130137). In the field of speculative grammar, the idea of a universal mental grammar was first proposed by Roger Bacon and developed by the Modistae grammarians (Thomas 2004: 55-66). Still, the tradition of normative grammar prevailed, and its primary object, Latin, continued to be considered the only intrinsically grammatical language, while vernaculars were regarded as unregulated idioms (Thomas 2004: 79). To quote Tavoni: "Latin was regarded as the only grammatical language; the vernaculars were by definition ungrammatical” (Tavoni 2000: 651; original emphasis), not only because they lacked codification in written grammars, but more importantly because they were seen as intrinsically lacking in conformity to rules. Latin was without qualification called litterae and grammatica (Posner 1996: 104; Lo Piparo 1986: 6-7 and 19), terms that indistinctly referred to both written and grammatical language. This binomial terminology was used by fifteenth-century Renaissance humanists such as Biondo and Poggio (see Sections 4.3.1 and 4.3.2; cf. Tavoni 1984: 33-35 and 106).

In De vulgari eloquentia (henceforth abbreviated DVE), Dante Alighieri conceptualizes the qualitative and ontological opposition between Latin and the vernaculars. He describes Latin in terms of the following categories and qualifications: (i) its status is secondary (locutio secundaria); (ii) its nature is (a) invented by art (artificialis), ${ }^{14}$ (b) governed by rules (grammatica, Dante, DVE $1,1,3),{ }^{15}$ (c) stable and unchangeable over time and space (quedam inalterabilis locutionis ydemptitas diversis temporibus et locis; [...] nec variabilis, Dante, DVE 1, 9, 11; lo latino è perpetuo e non corruttibile, 'Latin is eternal and incorruptible', Dante, Convivio 1, 5); (iii) its method of acquisition is by formal training (Dante DVE 1, 1, 3); (iv) its usage is (a) uniform (grammatica communis est, Dante, DVE $1,16,5)$ and (b) universally accepted and not subject to individual will (Hec cum de communi consensus multarum gentium fuerit regulata, nulli singulari arbitrio videtur obnoxia, Dante, DVE 1, 9, 11).

14 The vernacular follows custom, while Latin follows art (Dante, Convivio 1, 5), i.e. rules of grammar and rhetoric.

15 Dante claims that the Romans called "their secondary language" grammatica (Dante, DVE 1, 1, 3). In ancient Latin, there are a couple of instances of this association, e.g. Vitruvius, De Architectura 1, 18, 11 ad regulam artis grammaticae; Gregory of Tours, Historia Francorum, preface, si grammaticam artem excessero. Dante implicitly equates grammatica with Latin (Dante, Convivio 2, 12, 4; 3, 2, 18; 4, 6, 3 and Dante, DVE 1, 10, 1; 1, 11, 7; 2, 7, 6). 
At the same time, Dante attributes the opposite qualities to the vernacular; (i) its status is described as primary (prima locutio); (ii) it is (a) given by nature (naturalis), (b) lacks rules (sine omni regula), (c) and is subject to diachronic change and lacks stability (variatur successive per tempora nec stare ullo modo potest, Dante, DVE 1, 9, 10; Dante, Convivio 1, 5 lo volgare è non stabile e corruttibile 'the vernacular is unstable and corruptible'; (iii) it is learned by infants by imitation, Dante, DVE 1, 1, 2; (iv) it is not uniform (vulgare illustre is found in all cities of Italy and in none of them, Dante, DVE 1, 16, 4-5) and it is fluctuating due to individual arbitrariness, variatio sermonis arbitrio singularium fluitantis, Dante, DVE 1, 9, 11.

Dante assumes an ahistorical view of Latin, but a historical view of the vernaculars. He expresses an awareness of their historical changeability and geographical diversification (Dante, DVE 1, 9, 6-11; Dante, Conv. 1,5, Lo Piparo 1986: 10 f.). ${ }^{16}$ Meier (1941: 9) rightly argues that Dante adopts an evolutionary principle of explanation, but does not notice that Dante did not apply it to Latin. Dante derives Italian, along with Spanish and French, from one and the same language (idioma, Dante, DVE 1, 8, 5), but does not identify this language with Latin (Coseriu and Meisterfeld 2003: 132). Consequently, Dante does not have a diglossic concept of Vulgar Latin, but rather an idea of a permanent bilingualism existing between Latin and Romance ever since antiquity. This idea was to influence Renaissance conceptualizations of the linguistic situation of ancient Rome, possibly before, and definitely after the publication of $D V E$ by Trissino in his Italian translation $D e$ la volgare eloquenzia (Dante 1529) and by Corbinelli in its Latin original (Dante 1577).

\section{Intellectual contexts}

\subsection{Renaissance debates on language and its standardization}

In the diglossic culture of Renaissance Italy, there were debates about language cultivation and standardization. Both in the Latin Renaissance of the fifteenth century and in the vernacular Renaissance of the sixteenth century, several questions related to the choice of literary standard language were addressed. The Latin Renaissance humanists discussed what form of ancient Latin should be used and what models should be imitated. They aimed at reviving classical Latin as the main standard language of literature,

16 Dante also identifies an anthropic factor as the ultimate cause of linguistic change: the instability and corruptibility of human beings (Dante, DVE 1, 9, 6). 
scholarship, and culture. In order to re-standardize Latin usage, they developed Latin dictionaries, grammars, and orthographic handbooks. They also addressed questions concerning the identity (Italian or Latin), nature, variability, and historical changeability of the language of ancient Rome. The first records of this debate date from 1435. This debate marks a shift away from the medieval idea that Latin was by nature completely different from European vernaculars and toward a historicist position according to which Latin had once been a vernacular (cf. Campanelli 2014: 140-142).

In the context of this debate, a concept of Vulgar Latin was formed. The discussion of the identity and nature of ancient Latin was made possible through the humanists' encounter with ancient Roman linguistic awareness, as mirrored in metalinguistic terms for normative and divergent varieties of Latin in classical antiquity. These terms were in turn made accessible by the textual recovery of Cicero's rhetorical dialogues De Oratore, Orator, and Brutus in complete manuscripts (1421) and Quintilian's rhetorical handbook, Institutio oratoria (1416).

When the vernacular Italian Renaissance pursued its questione della lingua, another set of questions was at stake. Which language, Latin or the Italian vernacular (volgare), should be used? What regional variety of the Italian vernacular (volgare) should be chosen as the literary standard language and how should it be called? What form of the Tuscan language, the contemporary or the historical, should be the basis of the literary standard usage?

In the controversy on these issues, vernacular Italian philologists of the sixteenth century also addressed the question of the origin and emergence of the Italian vernacular. In doing so, they continued the discussion begun by the Latin humanists of the previous century. Vernacular Italian humanists partly opposed the corruption hypothesis by adopting the Aristotelian category of coming-into-being (genesis, generatio) as a linguistic explanation, or by making use of the category of accidental change (alloiosis, alteratio) as a theoretical model for linguistic change and continuity.

\section{The Italian Renaissance debate in the fifteenth century}

\subsection{Summary of the main positions}

In the discussion of the socio-linguistic situation of the ancient Roman speech community in the mid-to-late Republic and early Empire, the Latin humanists took different positions: 
a. The situation was bilingual: Latin and Italian as separate languages differed by nature as grammatical vs ungrammatical. This opinion is encountered in Leonardo Bruni.

b. The situation was monolingual: One single general Latin was used by the entire society, though with stylistic and functional variability. Biondo (1435) opposes the uncultivated popular variety of Latin "forma vulgaris" to the cultivated varieties, which he terms "forma poetica" and "forma oratoria”. Poggio Bracciolini (1450) refers to "sermo vulgaris hominis" as opposed to eloquent language. Filelfo (1451) opposes the concept of literary Latin, "sermo litteralis", to common Latin - viz. "sermo Latinus", which he qualifies by “communis”, "vulgaris” or “quotidianus”. Valla (1452) clearly distinguishes between the concept and term "sermo litteralis" and the concept and term of "sermo vulgaris".

\subsection{Theory of bilingualism: Leonardo Bruni Aretino 1435}

As indicated above (Section 1.2), many scholars have attributed the concept of Vulgar Latin as a low variety to Leonardo Bruni from Arezzo (1374-1444). However, their claims are based on an anachronistic interpretation. Bruni did not develop a diglossic concept of Vulgar Latin. As Strauss (1938: 42) underlines, Leonardo Bruni only proposed the idea of an ancient vulgar language, which he regarded as a particular and independent form of speech, as compared with literary standard Latin. He had no historicist perspective on ancient Latin, and accepts the medieval conception that vernaculars are ungrammatical. For this reason, he cannot possibly claim a typological identity between Latin and the vernacular. In his letter to Biondo (1435), he states that the Latin language of the educated (litterata lingua, sermo litteratus, sermo litteratorum, latine litterateque loqui) in antiquity, in the time of Terence and Cicero, was distinct from the popular language (vulgaris lingua, vulgaris sermo, sermo vulgi), just as in his own time. ${ }^{17}$

17 Quaestio nostra in eo consistit, quod tu apud veteres unum eumdemque fuisse sermonem omnium putas, nec alium vulgarem, alium literatum. Ego autem, ut nunc est, sic etiam tunc distinctam fuisse vulgarem linguam a litterata existimo (Tavoni 1984: 216), i.e. 'Our controversy consists in the fact that you [i.e. Biondo] assume that there was one single language among the ancients, and not a popular and a literary one. I think that the vulgar language at that time was distinct from the literary one, just as it is nowadays.' In the next sentence, Bruni specifies the adverb "tunc" to refer to the "per Terentii poetae et M. Tullii tempora", i.e. "in the time of the poet Terence and of Marcus Tullius [Cicero]'. 
Bruni's statement is open to different interpretations. His contemporary opponents - Flavio Biondo, Poggio Bracciolini, and Francesco Filelfo - understood it as an identification of the ancient Roman vernacular with contemporary Italian, as a claim of its difference from Latin, and thus as a theory of an ancient bilingualism between Latin and Italian. However, there is also another interpretation ultimately deriving back from L. Valla, who claims that Bruni posits a bipolarity between grammatical and ungrammatical varieties of one and the same ancient Latin, and apparently presumes a state of diglossia (Valla 1453: $\S \S 15-21$, §§ 80-86; Tavoni 1984: 262-263, 272-273). ${ }^{18}$

The former interpretation of Bruni's position is more weighty and likely. It is supported by conclusive internal evidence. Bruni himself explicitly equates the literary language with Latin. This equation occurs in Biondo and Poggio as well. The medieval binomial terms Latina and grammatica or litteratura (Section 2.3) accordingly survived until the fifteenth century (cf. Mazzocco 1993: 204). Moreover, Bruni regards Latin as a grammatical language learned through education. This criterion disqualifies the uneducated people from any possible command of Latin. Bruni (1435: § 32) identifies the differences between Latin and the vernacular (both the ancient and modern one) as follows:

The Latin language (Latina lingua) differs much from the vernacular (vulgari), mainly however in termination, ${ }^{19}$ inflection, semantic meaning, syntax, and accent. (see Tavoni 1984: 219)

Bruni (1435: $\S \S 33-40)$ exemplifies this with inflectional morphology in noun declension, e.g. supellex, supellectilis, and in verbal conjugation, e.g. fero (tuli, latum, sustuli, sublatum); semantic meaning; phonology; and phraseology, including syntax. He elsewhere implies, moreover, that the Latin lexicon differs from that of the vernacular. According to Bruni, the masses (turba) did not attend the plays of Plautus and Terence to understand them, but to watch the performance of physical actions (Bruni 1435: $\S 18$ ). He argues that the dramatic plays, when recited at theatres, were lexically incomprehensible to common people, even to the actors themselves, unless they had been instructed ahead

18 Tavoni appropriates Valla's interpretation (Tavoni 1986: 26, 1984: 8-15), but is refuted by Mazzocco (1993: 199-204). Schöntag (2017: 117, note 8) refers to the former interpretation (of Biondo, Poggio and Filelfo) as a misinterpretation, thus siding with Marazzini (1993b: 243, 245) and Valle and Patota (2006: 69).

19 In grammar, termination refers to a final element affixed to a word or stem to express some relation or modification of sense. A synonymous medieval and humanist Latin term is desinentia. 
of time (Bruni 1435: $\S 29$ ). These Latin plays do not pertain to the language of the crowd (nihil ad sermonem vulgi pertinent), Bruni concludes (1435: § 29).

Tavoni (1986: 26) claims that Bruni had a grammatical concept of language and that this concept influenced his conceptualization of the nature of the ancient vernacular (lingua vulgaris). According to Tavoni, Bruni regarded the vernacular as Latin in its lexicon, but not in its grammar (i.e. the volgare was Latin minus grammar), though Tavoni admits that Bruni would not have used the term Latin for the vernacular. As Mazzocco (1993) points out, Tavoni's interpretation does not hold good. Rather Bruni had the same grammatical-rhetorical conception of language as his contemporaries, e.g. Biondo. In his letter to Biondo, Bruni describes lexico-semantics, as shown above (Bruni 1435: § 19, § 29), and phonological variants of the same words (Varro, De re rustica 1, 2, 14, vellatura-vectura and vella-villa) as constituting the difference between the language of common people (vulgi sermo) and that of educated people (eruditorum sermo, see Bruni 1435: $\S 43)$. Furthermore, other sources testify to Bruni's combined grammaticalrhetorical conception of language. In the prefaces to his Latin translations, Bruni describes his regard for both lexical-semantic (latinitas and proprietas of single words) and rhetorical qualities (e.g. speech rhythm, oratio numerosa, and figures of speech, exornationes verborum et sententiarum) ${ }^{20}$

To conclude, in his letter to Biondo, Bruni is an advocate of the medieval or Dantean belief in a permanent bilingualism between Latin and Italian (as is also argued by Mazzocco 1993: 200). The same position is indicated in another source. In his criticism of one of the medieval translations of Aristotle's Nichomachean Ethics (by Grosseteste), Bruni touches on the relationship between literary Latin and the language of the populace. In the preface to his own translation (Bruni 1420; see Birkenmajer 1922: 160-161; Baron 1928: 80), he states that the medieval translator imprecisely renders some key concepts of the Greek text. Grosseteste has used words (delectatio and tristitia) from the crowd (e vulgo) instead of more semantically precise words (voluptas and dolor) from the usage of Cicero, Seneca, Boethius, Lactantius or Jerome. Bruni disapproves of this practice, alleging that the crowd is not a good teacher of linguistic usage (nam vulgus quidem haudquaquam probatus est loquendi magister). Bruni seems here to be referring to the usage of the crowd as a timeless entity, and as opposed to the usage of approved ancient Latin authors.

20 Bruni was reputed to be the foremost Latin stylist of his time, due to his observation of these qualities. Biondo acknowledges this in his letter to Bruni (De verbis Romanae locutionis, Biondo 1435: §§ 1-3; see Tavoni 1984: 197) with reference to the qualities mentioned above (latinitatis splendor, exquisita proprietas, numerositas, ornatus). 


\subsection{Theory of a monolingual internal situational or functional variation}

\subsubsection{Biondo 1435}

In his treatise De verbis Romanae locutionis (1435), the historian Flavio Biondo (1392-1463) explores the identity of the language of Roman oratory (orationes concionesque) and of general language (universa locutio, Biondo 1435: § 6). The Renaissance humanists' recovery of Cicero's previously unknown speeches brought to the fore the question of the language used by Roman orators in their public speeches: whether it was the contemporary Italian vernacular (aetate nostra vulgata idioma $^{21}$ or the grammatical language (grammaticae artis usus), ${ }^{22}$ which is called Latin (quod Latinum appellamus, Biondo 1435: $\S 8$ ). The recovery of Cicero's and Quintilian's rhetorical treatises (De Oratore, Orator, and Brutus and Inst. orat.) provided a key to answering this question. Biondo opposed the theory of bilingualism, arguing that there was in antiquity only one single Latin, that is, one single linguistic unity of Latin, regardless of social class, gender, degree of literacy and formal education (Biondo 1435: $\S 6, \S 37, \S 64, \S 86, \S 89$ ). However, this theory of monolingualism is not a theory of linguistic uniformity. Biondo recognized internal variability of ancient Latin both on the individual level, according to shifting linguistic ability (diversa dicendi facultas, Biondo 1435: § 64), and in functional levels, according to a tripartite socio-cultural division.

Quoting Cicero, Orat. 195, Biondo (1435: § 39) uses the criterion of rhythm to classify ancient Latin into three forms of diction (tres latinae dictionis formae): a poetical (forma poetica), an oratorical (forma oratoria), and a popular form (forma vulgaris). ${ }^{23}$ The two former represent learned Latin, and the latter unlearned Latin. He applies a historical perspective to the emergence of these forms from the common stage of Latin (par forma, communis dictio). Through the practice of modulation and public speaking (Biondo 1435: § 45), the first and second forms achieved a prestigious status (primariae). Owing to the neglect of cultivation among common people (inter vulgares), the third form was to remain artless, rude and

21 Biondo also refers to Italian as vulgare quoddam et plebeium loquendi genus, ut posteriora habuerunt saecula (Biondo 1435: §13) and quale nostra habet aetas vulgare (Biondo 1435: § 46). 22 In other passages, Biondo employs the terms latinitas litterata, latinitas litteraria, or latinitas grammatica, see De verbis Romanae locutionis, Biondo 1435: § 37, § 79, § 86, § 89, and § 111.

23 This classification of speech (locutionis partitio, Biondo 1435: § 46) is accordingly not, as Tavoni (1986: 25) claims, based on the doctrine of three stylistic levels (grand, middle and plain). Biondo only refers to these levels as optional styles of Roman oratory (Biondo 1435: § 74), thus evidently confining them within his forma oratoria. 
disreputable (incompta, squalida, ingloria). Biondo defines forma vulgaris as lacking rhythm (sine numero, Biondo 1435: § 39), just as Cicero had defined sermo vulgi (see Section 2.1 above). He adds that it lacked artfulness and rules (nulla arte, nullis habebatur regulis, Biondo 1435: § 42) and was used by common people (in vulgi possessione, Biondo 1435: § 42), for which reason it was known as vulgaris. It was not devoid of the quality of latinitas (Biondo 1435: § 43), but rather consisted of the same words as the two other major forms of diction (Biondo 1435: § 42).

Biondo discussed the lexicon (Biondo 1435: §§ 47-71), prosody (Biondo 1435: $\S \S 82-90)$ and grammar (Biondo 1435: $\S \S 91-100)$ of forma vulgaris in relation to his contemporary Italian (nostra vulgare). As parameters of his analysis Biondo used the concepts of latinitas '(correct) Latin' and vulgaritas 'vernacularity' (Biondo 1435: $\S 32, \S 86, \S 107$ ) with their variants: latinus and vulgaris (Biondo 1435: $\S 47, \S 78$ ) latine and vulgariter (Biondo 1435: § 21). In ancient grammatical theory, latinitas in its normative sense means correct Latin on three different levels: phono-lexicon, prosody (that is, vowel quality, intonation, and stress), and morphosyntax. Biondo's application preserved these levels, but modified the concept of latinitas. Instead of using it in its ancient sense, to designate correct Latin, Biondo used it to designate Latin as a linguistic type in contrast to other languages, in this case Italian. This conceptual modification or transformation of latinitas was necessitated and prompted by Biondo's object of comparison, namely contemporary Italian. This change from a normative to a crosslinguistic sense of latinitas made it a useful tool for dealing with the question at hand. ${ }^{24}$

In general, Biondo argued that the speakers of the forma vulgaris attained lexical latinitas, could recognize quantities of syllables in versified speech, ${ }^{25}$ and came close to grammatical latinitas. Concerning the Latin or Italian lexical nature of forma vulgaris, Biondo argues on the basis of the practice of Roman orators. He argued that the orators used Latin words (Biondo 1435: § 47, § 64, $\S 68$ Latina verba) that are dissimilar to words of the contemporary Italian vernacular (verbis nostris ... nequaquam adsimilia, Biondo 1435: § 47). The lexical register varied from high to plain style, depending on audience (Biondo 1435: $\S 41, \S 47, \S \S 69-70)$. Regardless of the stylistic level of words, the words of public speeches were Latin (Biondo 1435: § 68). Concerning the grammatical ability among users of forma vulgaris, Biondo argued that uneducated people did not know the rules of grammar by nature or by good usage (nec naturae aut

24 Biondo interprets passages referring to different orators' use of correct Latin in Cicero (on Flaminius, Brutus 109, on Curio, Brutus 210, and in general, Brutus 258) as evidence for the use of Latin in a crosslinguistic sense in contradistinction to contemporary Italian.

25 Biondo concludes this from Cicero, Orator 173. 
bonae consuetidine munere). Though they deviated from grammatical latinitas in morphology and syntax (Biondo 1435: $\$ \S 91-93$ ), they were not too far from it. To confirm his position, Biondo claimed that the quality of grammaticality is intrinsic to vernaculars (Biondo 1435: § 100 idiomatis natura insitum), even among users of the most corrupt vernaculars (corruptissima etiam vulgaritate loquentibus, Biondo 1435: § 100, cf. Coseriu and Meisterfeld 2003: 155).

Biondo (1435: §§ 72-73) explicitly refrained from discussing his topics from an exclusively rhetorical perspective, that is, from within the domain of ornatus in classical rhetorical theory. He states that he confines his perspective to the phono-lexical form of the Roman language, as opposed to its interior syntactic and stylistic structure (Biondo 1435: $§ 72$ verba vs characteres, locutio vs compositio, cortex vs medulla). Biondo's reason is that the lexical base of Latin in classical antiquity was almost always the same, or at least semantically comprehensible to everyone, regardless of the degree of its rhetorical elaboration in the three stylistic levels (the grand, middle, and plain, Biondo 1435: § 73).

To conclude, Biondo proposed the concept of Vulgar Latin as a historical socio-situational variety of ancient Latin designating artless, unlearned usage, as opposed to elaborate, learned usage. In reviving and modifying the concept of latinitas, he developed a lexico-grammatical perspective, in accordance with the specific levels or contents of latinitas in ancient linguistic theory (viz. phonolexicon, prosody, morphosyntax). Tavoni (1986: 27) argues that Biondo has a rhetorical perspective. Biondo himself claims to have a non-rhetorical perspective.

\subsubsection{Poggio Bracciolini 1450}

In his Disceptatio convivalis, book 3, Poggio raises the question of whether the ancient Romans (prisci Romani) spoke Latin as their natural vernacular and whether the language of educated people was distinct from the popular language. Poggio advances different kinds of arguments. First, he proposes an ethno-linguistic proof of the Latin identity of the language spoken by the ancient tribe Latini:

The language that was in common use among the Latins ought to be Latin. [...] Consequently, from the Latins the language is called Latin, which they, not others, used by then. (Poggio 1450: $§ 14$ and $\S 17$ )

Secondly, he argues from a collection of evidence from ancient authors (mainly Cicero, De oratore, Orator, Brutus, Quintilian, Varro, Gellius) that all ancient Romans, even uneducated people (vulgus imperitum), spoke Latin publicly and privately, and thus used Latin as their vernacular (Poggio 1450: §§ 29-126). 
Poggio calls attention to passages on the quality of latine loqui in ancient linguistic theory and on the use of Latin words in the context of spoken language. As regards references to latine loqui, he seems, like Biondo, to construe them in a crosslinguistic contrastive sense, as opposed to Italian, rather than in their original normative sense.

From Quintilian, Inst. orat. 1, 6, 27, on the alternative inflection of senatus (-i and $-u s$ ) and the distinction 'to speak Latin' (latine loqui) versus 'to speak grammatically' (grammatice loqui), Poggio concludes:

From this it is clear that everyone spoke Latin, but not everyone spoke grammatically [...]. Consequently, everyone spoke Latin, but the learned more correctly, emendatius. [...] For the learned judged by systematicity (ratio), what the others attained by usage (usus). (Poggio 1450: §§ 38-39)

Poggio argues that ordinary speech and eloquent speech did not differ in lexicon, but only in rhetorical ornamentation. Quoting Quintilian, Inst. orat. 12, 10, 43, Poggio concludes:

From this it is clear that the language of common and eloquent people was the same as regards the semantic precision (sermonis proprietas), but that it differed in rhetorical style (elocutio) and embellishment (ornatus). (Poggio 1450: § 41)

When commenting on lexical differences of style in contemporary Italian, Poggio returns to this diaphasic view of linguistic variation in ancient Latin:

The same may also have been the case in the Latin language, namely that although the words were common to all (communia omnibus verba), the eloquence and elegance of the words were not so. (Poggio 1450: § 74)

To conclude, Poggio revived the ancient concept of sermo vulgaris as a diaphasic variety on the basis of his interpretation of Quintilian.

\subsection{Theory of a divergence between literary Latin and common Latin}

\subsubsection{Francesco Filelfo (1451-1473)}

In his letter to Francesco Sforza (1451), Filelfo (1398-1481) continued the debate between Biondo and Leonardo Bruni on the linguistic situation of ancient Rome (Filelfo 1451: §§ 1-2). Filelfo suggests that the linguistic situation in the late Republic - from Plautus and Terence to Cicero and Caesar (Filelfo 1451: § 3) was monolingual, but at the same time was marked by a difference between 
ordinary or common Latin (oratio forensis, popularis, Filelfo 1451: $§ 4$; communis et quotidianus loquendi usus, Filelfo 1451: § 8) and literary Latin (sermo literalis), the language of poets and philosophers (Filelfo 1451: §§ 5-7; cf. Tavoni 1984: 174-175). To demonstrate this difference, Filelfo makes a typological comparison with other speech communities. He claims that the linguistic situation of ancient Rome was similar to the state of diglossia among Jews, Greeks, Egyptians, Arabs, Syrians, and Persians in his own time. He underlines that the divergence between ordinary language and literary language does not make them different languages; the differences instead make up a single linguistic system (Filelfo 1451: § 9):

I know that Jews and Greeks, and I have learned that Egyptians, Arabs, Syrians, Persians, and in the same way all other nations, who have a particular grammar, when employing one literary language, sermo litteralis, and another vernacular, sermo vulgaris, the literary language is more refined (limatior) and possibly more semantically precise (proprius) than the mother-tongue, but is still not another language (non alius) nor completely different (omninoque diversus) in the inflectional variation of words (dictionum variatio), in declension (declinatio), pronunciation (enunciatio) and desinence (desinentia, i. e. use of inflectional suffixes, termination). (Filelfo 1451: $§ 9)^{26}$

Filelfo's statement may be interpreted as a claim of a weak diglossia in Ferguson's sense (see Section 1.2 above, footnote 5). Such an interpretation is confirmed by the historically well-known diglossia of the Greek, Arabic, and Persian language communities in the Middle Ages and the early modern period.

In the letters to Maria Blanca (1463) and Lorenzo de' Medici (1473), Filelfo contrasts Latin in general (latinitas, Latinus sermo) with literary Latin (literatura, ${ }^{27}$ literalis sermo) in the time of the late Roman Republic (from Plautus and Terence to Cicero and Caesar):

The Latin language at that time was very close (admodum proxima) and similar (persimilis) to the literary language (litteratae), but now it is so different (dissimilis) that it appears to have become completely barbaric. (Filelfo 1463: § 3 [De Keyser 2015 (2): 908, lines 33-34])

Are the literary language and the Latin language (sermo literalis et latinus) one and the same or entirely diverse? They are neither the same nor different in every respect (nec ex omni parte alius). (Filelfo 1473: § 12)

Just as it was one thing to speak Attic and another to speak grammatically among the Athenians, the same difference also existed among the Romans, so that the principles of

26 Celenza (2009: 237) has called attention to this passage, but not as evidence of Filelfo's notion of diglossia in other speech communities.

27 The term litteratura refers to both inflectional morphology (Filelfo 1473: §§ 59-62) and literary language (such as non-dramatic poetry and philosophical discourse, Filelfo 1451: §§ $5-8)$. 
Latin (latinitatis ratio) and of literature (literaturae) were different, but this difference was however very small (sed ea tamen admodum parva). (Filelfo 1473: § 59)

Filelfo exemplifies this with heteroclitic words. Twofold nominal inflections according to the 4th or 2nd declension (e.g. senatus with $-i$ or $-u s$ ) and the 3rd or 1st declension (barbaries, -ei vs barbaria, -iae) are referred to as constituting instances of the difference between Latin and grammatical/literary inflection (Filelfo 1473: §§ 59-60).

Most importantly, Filelfo does not coin the term Vulgar Latin, but only describes general Latin with a number of qualifications: "vulgaris et omnibus notus" (Filelfo 1451: § 18), “communis et quotidianus loquendi usus" (Filelfo 1451: § 8), "doctis indoctisque communis" (Filelfo 1473: § 12), "materna ipsa vernaculaque lingua” compared to Greek koiné (Filelfo 1451: § 12), "quotidiana vulgarisque" (Filelfo 1473: § 17), "vulgaris et omnibus communis" (Filelfo 1473: $\S 41$ ), and "vulgaris et omnibus cognitus" (Filelfo 1473: § 63).

He recognizes a normalizing effect of literary Latin on general Latin, when the latter becomes corrupted:

I mean, the Latin language was popular (Latinus sermo vulgaris erat) and known by all et omnibus cognitus), but the literary language (litteralis) was not at all so, and was only known by the experienced and learned, however it was of such a nature that it corrected and nourished corrupt Latin. (Filelfo 1473: § 63)

\subsubsection{Lorenzo Valla 1452, 1453}

In De linguae Latinae elegantia, Lorenzo Valla (1407-1457) attempted to restore the ancient Roman language on the basis of the usage of prose writers, namely the greatest philosophers (summi philosophi), orators (summi oratores) and jurists (summi iurisconsulti). This restoration aimed to bring about a revival of Roman culture. He mainly comments on morphological, lexico-semantic, and phraseological features.

In two fictional dialogues between himself and Poggio, Antidotum in Pogium: liber II (Valla 1452) and Dialogus: libellus secundus (Valla 1453), Valla tries to refute Poggio's position in Historia convivalis. These dialogues take the form of a metadiscursive criticism of Poggio's position and a re-interpretation of Bruni's position. Valla and Poggio held different opinions on whether ancient Latin was an artificial language of the learned or a living language of the common people. Valla accepts the medieval idea of Latin as grammatical and vernaculars as ungrammatical (Valla 1452: $\S 195,1453$ : $\S 50$, $\S \S 80-81$ ). To refute Poggio's position, Valla resorts to the strategy of employing the term Latin (latine loqui) in two different senses: either (i) in a stylistic sense, referring to 
observation of the usage of learned people (consuetudo peritorum) as an alleged rhetorical virtue, or (ii) in a crosslinguistic contrastive and typological sense, according to which Latin is the language both of the ancient and modern Romans, so Italian can be called modern Latin. Valla does not consider Latin in its normative sense (correct Latin). Valla takes latine loqui in Quintilian (Inst. orat. $1,6,27)$ as an instance of the stylistic sense of Latin, as a quality of the orators and the learned in their conformity to rhetoric (Valla 1453: § 38), in contrast to Poggio, who interpreted it as referring to the Latin vernacular in a crosslinguistic, contrastive sense, as compared with Italian. After that, Valla in his dialogue switches to a typologically contrastive use of the term Latin:

The interlocutor Poggio says: "Have I not said that all Romans spoke Latin (latine), but the learned more correctly (emendatius, § 43)?”

The interlocutor Valla answers: "I do not understand why you say 'more correctly' (emendatius). I admit that some people may speak more ornately, in a more lofty way, and more eloquently than others, but not 'more Latin' (non latinius), if all the Romans had the Latin language in common (communis lingua latina, § 44). [...] If the ancient Romans (prisci Romani) did not speak in more Latin way (latinius), mutually, it amounts to nothing, what you are saying, that the learned spoke more correctly (emendatius, § 45)”. (Valla 1453: §§ 43-45) ${ }^{28}$

Commenting on Quintilian (Inst. orat. 12, 10, 43), Valla writes: "Behold what Leonardo stated, that there was one popular (vulgaris) and another learned language (eruditus sermo), something you completely deny. If this difference was great, Leonardo was right; if it was small and almost nothing, you win" (Valla 1453: § 21). Thus, Valla redefined the difference as a question of difference in degree rather than in nature, but he does not express his opinion of the degree of this divergence, i.e. whether it was great or weak, despite declaring such a purpose (Hoc ipsum quantum distantiae erat querimus, i.e. 'Let us explore this, how far the distance was', Valla 1453: $§ 77$ ). By analogy with contemporary Italian, however, he indicates that the high variety differed greatly from the low variety in phonology and in grammatical features, such as the use of definite article, declension of nouns, (present) participle, gerund, supines and inflection in general (derivandi usus). The lack of such features in contemporary Italian serves as the basis of the implicit assumption that they did not occur in the ancient low variety (Valla 1453: $\S 83, \S \S 85-86$ ). Valla avoids expressing his own opinion, since his stated purpose is only to oppose Poggio’s opinion (Valla 1453: § 87).

28 Concerning the inflection of Latinus as a linguistic term, the ancient Latin grammarian Pompeius Maurus (see Keil 1868: 153, lines 13-25) remarks it takes the comparative and superlative degrees if referring to the form of usage and style (si ad elocutionem respicit), i.e. the normative sense of Latin, but not if referring to a language as used by a nation (si a gente; cf. Kramer 1998: 63), i.e. the typologically contrastive sense of Latin. 
Valla asserts that there is a historical continuity between popular Latin and the Italian language of his own time (Valla 1453: § 25, § 73). Poggio had made a terminological distinction between Romana lingua as modern Italian and Latina lingua as ancient Latin. Valla retains the ancient binomial whereby lingua Latina is equal to lingua Romana both for ancient Latin and for contemporary Italian (Valla 1452: 195). Thus, Valla combines his notion of an ancient diglossia with his diachronic perspective on the continuation of Latin until his own time.

Why did Valla not state or develop a clearer concept of and terminology for Vulgar Latin? The answer seems to be that his humanistic Latin program of language education and the prevailing situation of language policy dissuaded him from assuming too great a distinction between the popular Latin language and the literary Latin of antiquity for the following reasons:

1. His program for a revival of Roman culture was based on a single Latin language system ("As many nations have one single code of laws, the Roman language is single", Valla writes in the preface to De linguae Latinae elegantia, book 1).

2. There was a socio-political danger with acknowledging a Latin vernacular tradition independent of classical Latin since antiquity, namely that Rome would run the risk of losing the competition for linguistic superiority with Florence (Mazzocco 1993: 77-79; Nauta 2009: 278).

\subsection{Theory of the historical change of ancient Latin}

\subsubsection{Guarino of Verona 1449}

In a letter to Prince Leonelle d'Este, De lingue Latine differentiis, Guarino of Verona (1374-1460) considered the nature (vis) of ancient Latin, its diachronic change (differentia) and its decline (ruina, Guarino 1449: § 6) in order to answer the question "what was the language of the Roman ancestors of the Italians: contemporary Italian or grammatical Latin"? Guarino distinguished between two types of Latin, based on their method of acquisition: (i) Latin in a non-normative sense, and (ii) Latin in a normative sense (Guarino 1449: § 8). In the former sense, Latin was learned by usage without method and rules (sine ratione, sine regulis) and was used by rural and urban people (urbani et rustici). It conformed to its own grammatical regularity, as an inherent and natural quality, among users devoid of formal grammatical education (Guarino 1449: § 46), in analogy with contemporary vernacular Byzantine Greek (Guarino 1449: § 45). Thus, uneducated persons were able to speak and understand Latin well (bene, Guarino 1449: § 34). In the second sense, Latin was acquired by formal training (studio et arte), and this refers to correct 
Latin, i.e. Latin without phonetic faults (barbarisms) and morpho-syntactical errors (solecisms, Guarino 1449: § 9). Guarino despised the contemporary Italian vernacular (materna, plebeia, vulgarica), considering it unworthy of the name of Latin. This testifies to the survival of the medieval use of the term Latin to refer to the vernaculars, a use which the Latin humanists tried to eradicate in their endeavor to revive classical Latin.

In his survey of the internal historical changes of Latin in antiquity (Guarino 1449: §§ 12-21), Guarino classifies ancient Latin into four successive stages (viz. lingua prima, lingua secunda, lingua tertia, lingua quarta), drawing on Isidore's periodization of Latin into prisca (proto-Latin, 1200-850 AD), Latina (Latin in the Kingdom of King Latinus, from ca. 850 BC), Romana (Republican Latin, from 509 $\mathrm{BC}$ ), mixta (from the time of Roman Empire at its high point of expansion). As regards the pre-republican stage, Guarino says that people learned Latin through usage (consuetudine) rather than through formal training (ratione et artificio, Guarino 1449: $\S 17$ ). Otherwise, Guarino only aims to prove the theory of monolingualism, which implies that in the pre-republican and republican periods the entire population spoke and heard Latin (Guarino 1449: § 22, § 52) in contrast to its restricted use among the learned in his own time (Guarino 1449: § 33) after the language deteriorated as a result of interference from the language of Goths and Langobards (Guarino 1449: § 21 and § 52).

In general, Guarino understands the changes in Latin during the first periods as a development towards cultivation and refinement. The culmination in the third period (Guarino 1449: $\S \S 18-19)$ was followed by a general decline caused by the influence of foreign nations speaking Latin incorrectly (inquinate loquentium, Guarino 1449: § 21). As Mazzocco (1993: 55-56) notes, Guarino agrees with Biondo in arguing in favor of a monolingualism of Roman antiquity, but displays a greater sensitivity to the chronological development of ancient Latin, though without precisely relating it to the two types of Latin - unlearned and learned - which he had identified.

\section{The Italian Renaissance debate in the sixteenth century}

\subsection{Summary of the main positions}

In the fifteenth and sixteenth centuries, Italian humanists held different opinions and proposed different theoretical models of the historical formation of Italian: 
a. As a mixed language resulting from linguistic corruption through external impact (Biondo 1435). Barrius (1554) presumes such a deterioration of the ancient low variety "lingua Latina vulgaris".

b. As a mixed language, emphasizing its newness and vitality in relation to ancient Latin, (e.g. Bembo 1525; Muzio 1532; Cittolini 1540; Tolomei 1555; Varchi 1570).

c. As an internal natural change of ancient Vulgar Latin (Castelvetro 1572, "la lingua latina volgare”; Cittadini 1601, “antica lingua Latino volgare”).

\subsection{Corruption hypothesis}

The disintegration of ancient Latin after the invasions of Germanic tribes was also a question addressed by the Latin humanists of the fifteenth century. The historian Flavio Biondo provided an answer in accordance with Italian national identity. In his corruption hypothesis, the vernacular (volgare) emerged and was formed as a mixed language through a process of barbarization, where Latin was mixed with the language of Germanic tribes and disintegrated as a linguistic system. Language contacts with Germanic-speaking nations, such as the Goths and Langobards, and the Langobardian subversion of Roman culture, were regarded as main causes of the formation of Italian. ${ }^{29}$ This hypothesis was immediately accepted by other Latin humanists, e.g. Guarino Veronese (1449) and Filelfo (1473). It gained ground in the Italian Renaissance during the sixteenth century. Spanish and Portuguese philologists also applied it to the origin of Spanish and Portuguese. $^{30}$ The corruption hypothesis enjoyed almost universal scholarly approval until Friedrich Diez (Melzi 1966: 159-160; Schlemmer 1983a: 25-137).

\subsection{Corruption-generation hypothesis}

In Prose della volgar lingua (written ca. 1505, published 1525), Pietro Bembo comments on the linguistic situation of Republican Rome (Bembo 1525: 1, 6) and the historical formation of Italian (Bembo 1525: 1, 7). In doing so, he shows himself to be an exponent of the monolingualism theory and the corruption

29 Biondo (1435: § 110; Tavoni 1984: 214-215) and Italia illustrata (Biondo 1448-1458: 374); see Castner (2005: 166).

30 E.g. Antonio de Nebrija, Gramatica de la lengua Castellana (1492), Jean de Váldez, Diálogo de la lengua (1535), Berhard Jose de Aldrete, Del origen y principio de la lengua castellana (1606), and Duarto Nunes de Leao, Origem de la lingoa portuguesa (1606). 
hypothesis, but also contributes to some innovative perspectives. He proposes an ancient Greek-Latin bilingualism, which he compares with the contemporary parallel use of Latin and Italian. He points out the novelty of Italian as a linguistic entity in relation to Latin: "a new language (una nuova), which is the volgare, was formed and born." At the same time, he reconceptualizes the qualities of the vernacular (Bembo 1525: 1, 3): the vernacular (la volgar lingua) is native (natia), one's own (propria), natural (naturale), and domestic (domestica), in contrast to Latin, which is foreign (straniera, istrana) and non-natural (non naturale).

All this paved the way for a more thorough redefinition of the historical and qualitative relationship between Latin and Italian. Claudio Tolomei, Girolamo Muzio, Alessando Cittolini, and Benedetto Varchi did not accept Italian's inferior status as a corrupt Latin (Latina corrotta). In their emphasis on the newness of Italian in relation to Latin, some of them developed a new model of cyclic processes, namely the theory of a corruption-generation, i.e. that Italian was born out of the death of Latin. In doing so, they resorted to Aristotelian natural philosophy, according to which changes in nature are explained as either a ceasing-to-be (phthora, corruptio), coming-to-be (genesis, generatio) or qualitative change of accidental characteristics (alloiosis, alteratio). ${ }^{31}$ In explaining the emergence of Italian, Tolomei, Muzio, Cittolini, and Varchi adopted the second category, with its principle "the corruption of one thing is the generation of another" (Arist., De generatione et corruptione, 319a 20-21). ${ }^{32}$ Varchi rejects the alteratio model, since he interprets the concept of Italian as Latina corrotta as implying an accidental change or modification of Latin. Italian would in this case be an altered form of Latin (alterata), not another (altra) new entity. ${ }^{33}$

The concept of generated languages served as the point of departure for some conceptual metaphors (cf. Faithfull 1953: 290-291): (a) the metaphor of the life and death of languages; (b) the metaphor of dead and living languages, according to which Latin was considered either dead or half-dead and the

31 Aristotle, Physics, V, 1-2, 224a 21 - 226b 17; Arist., On generation and corruption I, 3-5, 317b 1 $-322 \mathrm{~b} 33$.

32 Tolomei, Il Cesano della lingua Toscana (1555), Subri's edition (1975: 36) 'la corruzione de le cose è sempre vera ragione de la generazione de l'altre'; Cittolini, Lettera in difesa della lingua volgare (1540), 'fol. 3r: chi è che non sappia che la corrozzion d'una cosa è la generazion d'un' altra?', and '6r la Latina è morta e sepolta ne' libri [ ... ] la volgare è viva'; Muzio, Per difesa della volgar lingua (1532) (1582 in R. Sodana’s edition [1994: 236-237]); see Schunck (2003: 21); and Varchi, L'Ercolano (1570), Vitale's edition (1979: 32), see also Schunck (2003: 22).

33 Varchi, L'Ercolano (1570), Vitale's edition (1979: 33-36). Tavoni misleadingly states that Varchi in Ercolano "makes full use of the Aristotelian notions of alteratio" (Tavoni 1998: 47), though he also underlines Varchi's use of the corruptio-generatio hypothesis. 
vernacular living (Schunck 2003: 31-45); (c) the metaphor of mother- and daughter-language: Latin as mother and the individual Romance vernaculars as daughter-languages.

\subsection{The hypothesis of vulgar Latin}

\subsubsection{Gabriel Barrius, 1554}

Gabriel Barrius (1506-1577), a Latin humanist and historian from Francica in Calabria, is a less known Renaissance scholar, who endeavored to defend Latin in the Italian debate on language cultivation (questione della lingua) in his threevolume Pro lingua Latina (1571 [1554]). He also wrote a historical-geographical study of Calabria, De antiquitate et situ Calabriae (1571). In the former treatise, Barrius defends the position of ancient and humanist Latin against the views of Bembo, who had relegated Latin to the status of a foreign and non-domestic language.

To defend Latin's position as a natural and domestic cultural legacy of Italy, Barrius within the framework of corruptio, developed a concept of Vulgar Latin as a low variety (latinus vulgaris sermo, quotidianus vulgaris sermo) that deteriorated into Italian because of contacts with the Goths, while the high variety (Latina regularis lingua, grammaticus latinus sermo) remained unspoiled and undamaged (Barrius 1571 [1554]: 135, 170-172). To defend Latin as a national language, Barrius raises and answers a rhetorical question:

If the Latin vernacular from Latium is ancestral to the Latin and Roman nations as the native, indigenous, domestic, everyday, common, public, popular language (vulgaris sermo), why is grammatical, literary, regular, artistically produced Latin not ancestral to itself? [...] Accordingly, literary Latin (Latinus literalis sermo) is definitely ancestral (patrius) to the Latin nations, native, our own and peculiar to us (nativus, proprius et particularis). (Barrius 1571 [1554]: 99).

All metalinguistic attestations of popular language (sermo vulgaris), popular words (verba vulgaria), words of common people and the rural population (vulgi et rusticorum vocabula), and everyday language (quotidianus sermo) refers, according to Barrius, to one and the same linguistic entity, Vulgar Latin (latinus sermo vulgaris, Barrius 1571 [1554]: 226). Barrius points out that the concepts of ordinary language (vulgaris loquendi modus) and elevated language (singularis loquendi modus) are relational. He qualifies ordinary language with a number of adjectives, viz. everyday, popular, public, and common to everyone (quotidianum, populare, publicum, et commune omnibus, Barrius 1571 [1554]: 226). He 
regards elevated language as artful, rare, prominent, and not common by nature to everyone (artificiale, rarum, excellens, non omnibus natura commune, Barrius 1571 [1554]: 226). Barrius repeatedly qualifies vulgaris Latinus sermo with a long set of adjectives, viz. native, vernacular, everyday, familiar and popular (nativus, vernaculus, quotidianus, familiaris, popularis, Barrius 1571 [1554]: 235, cf. 99, 168). He uses all these qualifications in order to represent spoken Latin as a national Italian language and thus to oppose the claims of Bembo (Section 5.3).

Furthermore, Barrius transformed the medieval theory of bilingualism into a theory of diglossia in Ferguson's sense (Section 1.2, footnote 5), apparently a high-level one. In the preface, he certainly describes his work as a search for the existence of a bilingual co-existence of Latin, Latinus sermo, and the vernacular, vulgaris sermo, since antiquity, but in the course of his treatise he applies the term Latin to both of these entities, which means that he presupposed the existence of two varieties of one and the same language, namely Latin, rather than two different languages, as Laureys (2010: 30) observes. This clearly means that Barrius presumed that a state of diglossia (in Ferguson's sense) existed in ancient Rome. The medieval notion of Latin as grammatical and the vernacular as ungrammatical pervaded his linguistic thought (Barrius 1571 [1554]: 11-12; Laureys 2010: 32). His didactic views on written and grammatical Latin as having been a second language ever since antiquity guided his theorizing, because mastering Latin has always required formal study.

Barrius clearly underlined the qualitative difference between the high and low varieties. ${ }^{34}$ Like Valla (1453: § 85; cf. Section 4.4.2), Barrius (1571 [1554]: 169) thought that Vulgar Latin, as a linguistic type, lacked noun declension, verb conjugation, participles, gerunds, supines, degrees of comparison, and neuter gender. Concerning the lexical stock, Barrius regarded a great number of words as originally common to both Vulgar Latin and standard Latin (latinitas), including amo, curro, fabrico, subito, quando, supra, intra, intro, infra, poeta, via, casa, porta, and iustitia. On the other hand, standard Latin possesses many words not known to Vulgar Latin, and vice versa. Authors of the Latin language took rude and formless words from common popular usage, formed and fashioned them, and endowed them with Latin citizenship (Barrius 1571 [1554]: 176, 190). They also formed new words from extant roots, such as perago from ago, perlego from lego, and nauta from navis. Barrius perceived the difference between Vulgar Latin (Latina vulgaris) and grammatical Latin (Latina regularis lingua) as a relation between natura and ars, comparing the former to a rough stone and the latter to a bas-relief (Barrius 1571 [1554]: 190). In several passages, Barrius

34 Barrius (1571 [1554]: book 2, 190): Inter latinitatem et vulgaritatem longe plurimum interest, i.e. 'Between the Latin language and the vernacular there is a great difference'. 
comments on the historical relationship of Vulgar Latin to regular or grammatical Latin. He traces the high variety back to the early Kingdom (Barrius 1571 [1554]: 132, 164).

Barrius also justifies his theory of the diglossic situation of ancient Rome with reference to the similar situations in the Greek and Jewish speech communities. They have two kinds of language (duo loquendi modi), an ordinary one, common to everyone, and an elevated one, which he equates and identifies with regular language. ${ }^{35}$

\subsubsection{Castelvetro 1572}

The Italian philologist Lodovico Castelvetro (1505-1571) explained the historical origin of Italian as an internal development from Vulgar Latin. In doing so, he formally adhered to the corruption-generation hypothesis, but in fact he abandoned it (Faithfull 1953: 286). In his notes (Giunte) on Bembo's Prose della volgar lingua (1572), Castelvetro expounds his views on the nature and variation of ancient Latin (Castelvetro 1714 [1572]: I, 18-31) and on the transformation of ancient Vulgar Latin into Italian (Castelvetro 1714 [1572]: I, 31-37).

In his criticism of Bembo, Castelvetro developed the diglossic concept of Vulgar Latin. In postulating a diglossia (in Ferguson's sense) between noble, cultivated, and literary Latin as a high variety and popular Latin as a low variety, Castelvetro takes an intermediate position between the theories of bilingualism and monolingualism. In doing so, he interprets Leonardo Bruni's position in an unbiased way, well aware of the different conclusions drawn by Filelfo and Poggio on the one hand, and Valla on the other (Castelvetro 1714 [1572]: I, 26).

In relation to the medieval bilingualism theory, Castelvetro thinks that the grammar of Vulgar Latin differed from that of the Italian of his own time ("la lingua de' nostri tempi, chiamata volgare”, Castelvetro 1714 [1572]: I, 28), but that its lexical stock was similar. Castelvetro posits two social varieties: the language of orators, historians and poets and all writers of literary ambition, as opposed to the language of the people ("la lingua antica del volgo", Castelvetro 1714 [1572]: I, 29), spoken by people of the low classes and farmworkers (Castelvetro 1714 [1572]: I, 28-29). He also addresses the question of the mutual relationship between these two varieties. In his view, the literary variety was not so far from the popular one. They had grammatical features and a large

35 Barrius (1571 [1554]): book 2, 226): Graeci, Latini, et Hebraei [ ... ] duos loquendi modos habent: vulgarem communem omnibus et singularem, hoc est regularem. 
number of words and phrases in common. Castelvetro agrees with Poggio and Filelfo that written Latin was generally understood by the people ("la lingua latina scritta fosse intesa dal popolo universalemente”, Castelvetro 1714 [1572]: I, 29), but underlines the historical continuity of ancient popular Latin, in most of its lexicon, with the contemporary language ("presente linguaggio", Castelvetro 1714 [1572]: I, 29) and its terminological continuity as volgare (Castelvetro 1714 [1572]: I, 29). To quote Marazzini, "Castelvetro arrivava ad una formulazione abbastanza precisa del concetto di 'latino volgare’” (Marazzini 1999: 72). ${ }^{36}$ To express this concept, Castelvetro employs a definite term "la lingua latina volgare" (Castelvetro 1714 [1572]: I, 43), previously attested in Barrius in its Latin counterpart, but his terminology is not uniform. ${ }^{37}$

Addressing the question of the emergence of Italian, Castelvetro (1714 [1572]: I, 31) says that all that remains to investigate is when and how Vulgar Latin diffused and changed. In doing so, he divides the process into three periods: (i) before the Sack of Rome $410 \mathrm{AD}$, (ii) the rule of Goths in Italy, (iii) the rule of Langobards in Italy. In the first period, Vulgar Latin spread into the usage of higher classes. This social diffusion was caused by emperors and courtiers of foreign, non-Italian origin, who did not communicate in pure and literary Latin, but in Vulgar Latin (Castelvetro 1714 [1572]: I, 32). At the time of the Emperors Honorius and Arcadius, Vulgar Latin had spread to all the population in Italy (Castelvetro 1714 [1572]: I, 33). In this period, Vulgar Latin was uncorrupted and preserved its original grammatical features ("suoi primièri accidenti", Castelvetro 1714 [1572]: I, 33). In the second period, contacts with the Goths had only a limited effect on the Latin vernacular. People used an uncorrupted Vulgar Latin ("la latina lingua intera") until the Langobards arrived in Italy (Castelvetro 1714 [1572]: I, 34).

In the third period, Vulgar Latin was corrupted in the course of the first hundred years after the arrival of the Langobards (Castelvetro 1714 [1572]: I, 35). It underwent grammatical changes ("mutamenti accidentali", Castelvetro 1714 [1572]: I, 35) and began to take the form that it still has. Germanic grammar had a functional influence on Vulgar Latin, so that extant elements were modified to fit the usage of Germanic nations (e.g. the use of articles, the conjugation system

36 I.e. 'Castelvetro arrived at a rather precise formulation of the concept of "Vulgar Latin"'. 37 "lingua volgare antica" (see index of contents, s.v. lingua), "la lingua antica del volgo" (Castelvetro 1714 [1572]: I, 29), "la lingua latina volgare" (Castelvetro 1714 [1572]: I, 33, 35, 43), "la gentile lingua Latina” (Castelvetro 1714 [1572]: I, 33), "la latina volgare” (Castelvetro 1714 [1572]: I, 34), "la lingua latina dal popolo" (p. 34), "la lingua popolesca” (Castelvetro 1714 [1572]: I, 35), "linguaggio popolesco" (Castelvetro 1714 [1572]: I, 36), "lingua latina volgare” (Castelvetro 1714 [1572]: I, 76), “lingua popolare” (Castelvetro 1714 [1572]: I, 134). 
(Castelvetro 1714 [1572]: II, 55-56 and 132, notes on book 3, 15 and 31; see Schlemmer 1983a: 50-51). On the lexical level the Germanic impact was, according to Castelvetro (1714 [1572]: I, 35), limited to a few Langobardian cultural loanwords (cf. Melzi 1966: 166-167).

\subsubsection{Cittadini 1601}

The Italian philologist Celso Cittadini (1553-1627) discussed the same topics as Castelvetro: the sociolinguistic situation of the Roman Republic and Empire, and the transformation of Vulgar Latin into Italian. The sources of Cittadini's linguistic thought on these topics are two treatises: Trattato della vera origine e del processo e nome della nostra lingua and Trattato de gli articoli, both published in Venice in $1601 .^{38}$

Continuing Castelvetro's criticism of Bembo, Cittadini proposed a new theoretical model, namely to apply the third Aristotelian category of change, i.e. alteration, to linguistic theory. Cittadini argues that Vulgar Latin changed into Italian by a gradual process of accidental changes in grammar. The categories of substance and accidents are crucial to the alteration theory. The substance is identified with the lexicon and the accidents with grammar. The Italian vernacular is the same as Vulgar Latin in its stock of words, and has only been varied in its grammatical accidents, without the destruction of the lexical substance. Cittadini refers to Aristotle as "il Filosopho" (Cittadini 1601: 38r, 40r; cf. Schunck 2003: 96).

As intimated in Section 1.5, Cittadini's dependence on earlier sixteenthcentury Italian linguistic theorists, such as $\mathrm{Cl}$. Tolomei and L. Castelvetro, has been a subject of controversy. ${ }^{39}$ Tavoni claims that "the role of Cittadini, who

38 For surveys, see Vitale (1955: 44-47), Ward (1990: 97-111), Ward (1992: 57-69, 148-159), Werner (1999: 351-369), Pistolesi (2000: 113-120), Schöntag (2017: 124-125).

39 Since the end of the nineteenth century, Cittadini has been accused of committing plagiarism in his treatises Trattato della vera origine (Cittadini 1601) and Le origini della volgar toscana (Cittadini 1604); see Ward (1990: 109, note 3) with a list of references; Tavoni (1998: 76, note 110). As regards Le origini (Cittadini 1604), the accusation of plagiarism is unfair. Castelvetro acknowledges his debt to Tolomei, Castelvetro, and others; see Melzi (1966: 162). Trattato della vera origine (1601) only relies on Tolomei in a few places, as Faithfull (1962: 248) argues, and as Lüdtke (2001: 17) indicates, but contains many points of similarities with Castelvetro's ideas, as Faithfull (1962: 248-249) points out and Melzi (1966: 159-168) demonstrates by evidence, e.g. in the derivation of Italian from Vulgar Latin as a low variety. In these cases (either direct quotations or paraphrases), Cittadini does not mention his source. 
was formerly credited with postulating the idea of 'vulgar Latin', has been drastically reduced to utilizing, if not plagiarizing, both" (Tavoni 1998: 48). ${ }^{40}$

This statement requires clarification. In comparison with Tolomei, Cittadini is innovative in his hypothesis on Vulgar Latin. ${ }^{41}$ Tolomei's adherence to the corruption-generation theory prevented him from arriving at the concept of Vulgar Latin. His phonetic and morphological observations on Tuscan were certainly utilized by Cittadini in Le origini della volgar Toscana (1604), though not in Trattato della vera origine (1601).

In relation to Castelvetro, Cittadini made a number of improvements: he applied Isidore's periodization of ancient Latin to the diglossia theory, discussed literary evidence relating to Vulgar Latin, provided epigraphic documentation for spelling and sound changes being characteristic of Vulgar Latin (Ward 1990: 105-106), and developed a new theoretical framework for analyzing the transformational process from Vulgar Latin to Italian, viz. the "alteratio" theory, although Castelvetro was also on this track (Faithfull 1962: 249-250).

To begin with, Cittadini (1601: 1r) opposed the corruption hypothesis, by which Italian is derived from the corruption of classical Latin at the time of the Goths and the Langobards. Cittadini (1601: 1v) used Isidore's periodization of Latin into prisca, Latina, and Romana, mixta as the chronological context for deriving the Italian vernacular ("la lingua vulgare, nostra lingua") from Vulgar Latin. He identifies three internal stages of the Roman period (lingua Romana), (i) until the time of Ennius and Plautus, (ii) until the time of Caecilius and Terence, and (iii) until the time of Vergil and Livy (Cittadini 1601: 4r), and tries to elucidate their phonological and grammatical features from inscriptional and literary sources (Cittadini 1601: 7v-33r).

Cittadini adopted Castelvetro's diglossia theory of a social stratification of ancient Latin, namely with vernacular Latin as the low variety and cultivated Latin as the high variety, and also integrated it into his periodization of Latin.

In every period, both earlier and later, there have been two types of Latin in Rome: one rough and half barbarous, which was found among the populace, that is the unlearned Romans and foreigners, or I would say people of lower classes and rural population without learning; (Cittadini 1601: 2r)

40 Tavoni (1998: 48) argues that the polymath Claudio Tolomei (1494-1556) in unpublished treatises (1545-1556) innovated the understanding of the relationship between Latin and the Tuscan vernacular by his observations of a set of phonetic and morphological transformations from Latin to Tuscan.

41 Cittadini's innovation is emphasized by Faithfull (1962: 244), Schlemmer (1983b: 31-33), and Ward (1990: 101 and 110, note 13 with a list of references). 
[and] another variety cultivated by art and correct Latin, which was found among the noble writers and speakers and among educated people. (Cittadini 1601: $2 \mathrm{v}$ )

The bifurcation of ancient Latin into the diglossic co-existence of two synchronic varieties is repeated many times. ${ }^{42}$

Paraphrasing and quoting Castelvetro, Cittadini (1601: 2v) argues that the ancient Vulgar Latin "la lingua latina antiqua del vulgo" has been preserved by the Italians up to his time and that its ancient name, vulgare, remains the most appropriate term for it. Cittadini (1601: 55r-57r, 61v-62r) is convinced of the terminological continuity in designating the vernacular as Latin and the Italians as Latins, for instance in Dante, Petrarca, and Boccaccio. He refers to latino volgare in Boccaccio's Teseida (Cittadini 1601: 62r, 64r).

On the basis of Cicero (Brutus 258), Cittadini (1601: 34v) assumes that Latin deteriorated under the late Republic not only among low-class people ("la gente bassa"), but also among the writers ("gli Scrittori"). From his time, Cittadini argues "it was necessary to study the rules of Latin grammar or the works of ancient good writers of Latin in order to be able to speak well and purely (bene e puramente), i.e. Latin (cioè latinamente)" (Cittadini 1601: 35r). He continues: "Those who did not study were not able to speak Latin, but spoke with barbarisms, i.e. with vulgarisms" (Cittadini 1601: 35r). Cittadini here equates the high variety with good and pure language, and the low variety with barbarous language. The same equations also occur in another passage (Cittadini 1601: 44r, cf. 36r), where the low variety is viewed as lacking grammar ("senza grammatica"). Vulgar Latin is associated with an internal barbarization. For this reason, Cittadini describes Vulgar Latin as the younger sister of latina grammaticale (Cittadini 1601: 63r).

Cittadini makes a terminological distinction between ancient Vulgar Latin ${ }^{43}$ and modern Vulgar Latin. ${ }^{44}$ Cittadini argues that Vulgar Latin is the best term for referring to the Italian standard language of his time. He rejects the alternative terms Tuscan, Florentine, Cortigiana, and Italian (Cittadini 1601: 60r; cf. Ward 1990: 107-108).

42 "duae maniere di lingua” (Cittadini 1601: 37r); “due sorti di lingua [ ... ] una latina pura ed una vulgare” (Cittadini 1601: 42r); “due sorti di lingua latina” (Cittadini 1601: 44r); “due sorti di lingua, cioè pura e vulgare” (Cittadini 1601: 47v).

43 Trattato della vera origine: "la latina lingua antica usata dal vulgo" (index of contents, s.v. Gl'Italiani), "antica lingua Latina vulgare” (index of contents, s.v. ragione perche), "lingua latina antica del vulgo" (Cittadini 1601: 2v), "lingua vulgare de'latini” (Cittadini 1601: 39v), "questa lingua vulgare di antichi” (Cittadini 1601: 43r), "la lingua vulgare degli antichi Romani" (Cittadini 1601: 60r); Trattato de gli articoli: "vulgar latina dell'antico Popolo Romano” (Cittadini 1601: 1r), “purità dell' antica lingua vulgare” (Cittadini 1601: 1v).

44 Trattato della vera origine: "lingua latina vulgare" (Cittadini 1601: 64r), "latina vulgare" (Cittadini 1601: 63 v), "vulgar Latina” (Cittadini 1601: 64r). 


\section{Conclusions}

To conclude, ancient theorists on the linguistic variation of Latin did not conceptualize sermo vulgaris as a separate and distinct social variety, but defined it as a situational variety in contrast to a technical or rhetorical style, though not necessarily in contrast to correct Latin.

In the high Middle Ages, an ahistorical view of Latin as an artificial, invariable, and immutable or timeless secondary language, only learned by formal training, developed. Dante is an exponent of this view. The early humanists inherited this Dantean view.

When Vulgar Latin emerged as a concept in the Italian Renaissance, its meaning varied depending on the different choices of dimensions of variation, viz. diaphasic or diastratic; of perspective, viz. synchronic or diachronic; and other parameters, e.g. degree of typological identity (the relative presence of Latin or Romance features), contrast to pure and correct Latin (corresponding to the modern term classical standard Latin), diamesic opposition to written Latin, method of learning, and historical relationship to classical Latin as a period.

In the Italian Renaissance of the fifteenth century, a synchronic-diaphasic concept of Vulgar Latin was formed. In the Italian Renaissance of the sixteenth century, a diastratic-diachronic concept of Vulgar Latin was formed.

This article explores in particular the theoretical prerequisites and intellectual circumstances behind the emergence of the diglossic concept of Vulgar Latin. It argues that the concept of a distinct low variety of ancient Latin required some innovations in historical linguistic thought (points 1 and 2 below), but that it also interacted with the medieval tradition of linguistic thought on the nature of Latin and the vernacular (points 3 and 4) in the following respects:

1. A historicist view of ancient Latin as a historical vernacular, common to all, natural, and thus possible to learn without formal training, since all languages share a natural grammar.

2. An understanding of the variability and changeability of ancient Latin.

3. A rejection of the medieval view of the nature of Latin.

4. A synthesis of the fifteenth-century theory of monolingualism and the medieval theory of bilingualism regarding the linguistic situation of Roman antiquity.

In the synthesis of these two currents, some factors qualify as circumstantial prerequisites: 
5. Dante's exposition of the opposite natures of Latin and vernaculars, and its continuous impact on Italian Renaissance linguistic theorizing after the publication of De Vulgari eloquentia in Italian translation (Dante 1529) and in its Latin original (Dante 1577).

6. Leonardo Bruni's reception of the medieval and Dantean views on the nature of Latin and the vernaculars in his assumption of a Latin-Italian bilingualism in antiquity.

7. Lorenzo Valla's (1452-1453) re-interpretation of Leonardo Bruni's position as a state of permanent divergence between literary, learned Latin and common, unlearned Latin.

8. Valla's evident impact on Gabriel Barrius' (1554) theory of a strong lexical and grammatical divergence between ancient literary Latin and ancient vernacular Latin.

9. Valla's impact on Castelvetro (1572) in the latter's refined theory of a grammatical - but not lexical - divergence between literary Latin and popular Latin, and finally Valla's indirect influence on Cittadini's theory of Vulgar Latin (1601).

This article revises and clarifies the linguistic historiography on three points:

10. Dante Alighieri does not propose the diglossic concept of Vulgar Latin as a distinct low variety, but has a theory of a permanent bilingualism (Section 2.3).

11. Leonardo Bruni has incorrectly been credited with the concept of Vulgar Latin as a low variety of ancient Latin (Section 4.1).

12. Lorenzo Valla made an incorrect interpretation of Bruni's standpoint (Section 4.3.2).

Furthermore, the concept of Vulgar Latin as a low variety was based on a dualistic conception of ancient Latin, which presumed a contrast between literary Latin and non-literary Latin. Vulgar Latin was thus formed as a relational and oppositional counterpart to a high variety, viz. literary standard Latin, which in early modern terminology is termed pure or grammatical Latin, a term that in turn originated in the ancient terminology for referring to correct Latin, viz. latine loqui, sermo Latinus, sermo purus, or latinitas.

When the concept of Vulgar Latin as a low variety was formed in the Renaissance, it had a specific set of constituents. The concept referred to a separate and distinct social variety (namely the Roman popular language) that was in use among people without formal education, that could be traced back to the archaic period of Latin, and that changed in different historical stages in a dual process of accidental change and substantial continuity, that is, in a 
process characterized by grammatical and phonetic change and lexical continuity.

The Aristotelian category of change, alteratio, was modified to conform to linguistic theorizing aiming to explain the process of linguistic change in terms of the categories of substance and accident, specifically as a substantial continuity of lexicon and accidental change of grammar. This model served as the intellectual context and framework for Cittidini's concept of Vulgar Latin, which was a refinement of ideas proposed by Castelvetro.

\section{References}

\section{Primary sources}

Barrius, Gabriel. (1571 [1554]). Pro lingua Latina, 2nd revised edn. Roma/Rome: Josephus de Angelis.

Bembo, Pietro. 1525. Prose di M. Pietro Bembo nelle quali si ragiona della volgar lingua. Vinegia/Venice: Tacuino.

Biondo, Flavio. 1435. De verbis Romanae locutionis ad Leonardum Aretinum (letter to L. Bruni 1 April 1435). See text edition in Tavoni (1984: 197-215).

Biondo, Flavio. 2005. Italia illustrata: Text, translation, and commentary. Edited by Catherine J Castner. Binghamton, NY: Global Academic Publ.

Bonamy, Pierre Nicholas. 1756. Mémoire sur l'introduction de la langue Latine dans les Gaules, sous la domination des Romains, and, Réflexions sur la langue Latine vulgaire. In Mémoires de littérature, tirés des registres de l'Académie royale des inscriptions et belleslettres, vol. 24, 582-602 and 603-656. Paris: L'imprimerie royale.

Bracciolini, Gian Francesco Poggio. 1450. Utrum priscis Romanis Latina lingua omnibus communis fuerit an alia quaedam doctorum virorum, alia plebis et vulgi. In Historia disceptativa convivalis, book 3. Knoblochus (ed.), Poggii Florentini oratoris clarissimi ac sedis apostolicae secretarii opera, 1511 and 1513, fols. 20v-24v. Argentinae/Strasbourg: Johann Schott. See text edition in Tavoni (1984: 239-259).

Bruni, Leonardo. 1420. Leonardi Aretini in libros Ethicorum proemium. Printed 1469, 1504, 1530 as part of Ethica interprete Leonardo Aretino. Published in Birkenmajer (1922: 157-162), Baron (1928: 76-81).

Bruni, Leonardo. 1435. Leonardus Flavio Foroliviensi, letter to Flavio Biondo 7 May 1435: Quaerit an vulgus et literati eodem modo per Terentii Tuliique tempora Romae locuti sint. In Lorenzo Mehus (ed.), Leonardo Bruni Arretini Epistolarum libri VIII, vol. 2, Florentiae: Bernard Paperini, 1741, book 6(10),62-68. See text edition in Tavoni (1984: 216-221).

Castelvetro, Lodovico. 1714 [1572]. Le prose di M. Pietro Bembo nelle quali si ragiona della volgar lingua (...) con le giunte di Lodovico Castelvetro. Napoli: Bernardo Michele Raillard and Felice Mosca. 
Cittadini, Celso. 1601. Trattato della vera origine e del processo e nome della nostra lingua, scritto in vulgar Sanese, and Trattato de gli articoli. Venetia/Venice: Giovanni Battista Ciotti.

Cittadini, Celso. 1604. Le origini della volgar toscana favella. Siena: Marchetti.

Cittolini, Alessandro. 1540. Lettera in defesa della lingua volgare. Vinegia: Francesco Marcolino da Forli.

Dante, Alighieri. (ca. 1304). De vulgari eloquentia. Edited and translated by Steven Botterill. Cambridge: Cambridge University Press, 1996.

Dante, Alighieri. 1529. De la volgare eloquenzia. In Italian translation by Giovanni Giorgio Trissino. Vicenza: Ianiculo.

Dante, Alighieri, 1577. De vulgari eloquentia libri duo. Nunc primum ad vetusti et unici scripti codicis exemplar editi. In the edition of Jacopo Corbinelli. Parisiis/Paris: Corbon.

Filelfo, Francesco. 1451. Letter to Francesco Sforza. Text edition in Tavoni (1984: 274-280).

Filelfo, Francesco. 1463. Letter to Maria Blanca, 27 May 1463. In Francesco Filelfo, Collected letters: Epistolarum libri XLVIII. Edited by Jeroen De Keyser. Alessandria: Edizioni dell'Orso, 2015. See letter no. 19.01 .

Filelfo, Francesco. 1473. Letter to Lorenzo de' Medici. See text edition in Tavoni (1984: 281-296).

Guarini Veronese, Guarino. 1449. De lingue latine differentiis. Epistulario di Guarino Veronese, 3 vols, Venezia: C. Ferrari, 1915-1919. See Tavoni (1984: 228-238).

Muzio, Girolamo. 1582. Battaglie di Hiernonymo Mutio Guistinopolitano per diffesa dell' Italica lingua. Published by Giulio Cesare Muzio. Vinegia: Dusinelli.

Muzio, Girolamo. 1994. Battaglie per difesa dell'italica lingua. Text and notes by Rossana Sodano. Torino: Ed. RES.

Tolomei, Claudio. 1555. Il Cesano, dialogo di M. Claudio Tolomei nel quale da piu dotti huomini si disputa del nome col quale si dee ragionevolmente chiamare la volgar lingua. Vinegia: Giolito de Ferrari.

Tolomei, Claudio. 1975. Il Cesano de la lingua Toscana. Edited by Maria Rosa Franco Subri. Roma: Bulzoni.

Valla, Lorenzo. 1452 (printed 1540). Antidotum in Pogium: Liber secundus. In Eugenio Garin (publisher), Laurentius Valla, Opera omnia, vol. 1, 274-300. Torino: Bottega d'Erasmo, 1962.

Valla, Lorenzo. 1453 (printed 1540). Dialogus: Libellus secundus. In Eugenio Garin (publisher), Laurentius Valla, Opera omnia, vol. 1, 375-389. Torino: Bottega d'Erasmo, 1962. See Tavoni (1984: 260-273), comprising pp. 384-388.

Varchi, Benedetto. 1570. L' Ercolano. Published by Giovanni Gaetano Bottari. Milan, 1804.

Varchi, Benedetto. 1979. L'Ercolano. Reprint of the Milan edition 1804 (by Giovanni Gaetano Bottari) with an introduction by Maurizio Vitale. Milan: Cisalpino-Goliardica.

\section{Modern literature}

Adams, James Noel. 2013. Social variation and the Latin language. Cambridge: Cambridge University Press.

Baron, Hans (ed.). 1928. Leonardo Bruni Aretino: Humanistisch-philosophische Schriften.

Leipzig: Teubner. 
Birkenmajer, Alexander. 1922. Der Streit des Alonso von Cartgena mit Leonardo Bruni Aretino. In A. Birkenmajer (ed.), Vermischte Untersuchungen zur Geschichte der mittelalterlichen Philosophie, 157-210. Münster: Verlag der Aschendorffschen Verlagsbuchhandlung.

Bursill-Hall, Geoffrey Leslie. 1995. Linguistics in the later Middle Ages. In E. F. K. Koerner \& R. E. Asher (eds.), Concise history of the language sciences: From the Sumerians to the cognitivists, 130-137. Oxford: Pergamon.

Burton, Philipp. 2009. "Itali dicunt ozie”. Describing non-standard and low-register speech in Latin. In Carlo Carusco \& Andrew Laird (eds.), Italy and the classical tradition: Language, thought and poetry 1300-1600, 29-40. London: Duckworth.

Calboli, Gualtiero. 1994. Latino volgare e latino classico. In G. Cavallo, Cl. Leonardi \& E. Menestò (eds.), Lo spazio letterario del medioevo. 1. Il medioevo latino, vol. 2: La circolazione del testo, 11-62. Roma: Salerno.

Campanelli, Maurizio. 2014. Languages. In Michael Wyatt (ed.), The Cambridge companion to the Italian Renaissance, 139-163. Cambridge: Cambridge University Press.

Celenza, Christopher. 2009. The end game: Humanist Latin in the late fifteenth century. In Yanick Maes, Jan Papy \& Wim Verbaal (eds.), Latinitas perennis, volume II: Appropriation and Latin literature, 201-242. Leiden \& Boston: Brill.

Clackson, James \& Geoffrey Horrocks. 2007. The Blackwell history of the Latin language. Malden, MA \& Oxford: Blackwell.

Coseriu, Eugenio. 2008. Lateinisch-Romanisch: Vorlesungen und Abhandlungen zum sogenannten Vulgärlatein und zur Entstehung der romanischen Sprachen, bearbeitet und herausgegeben von Hansbert Bertsch. Tübingen: Günter Narr.

Coseriu, Eugenio \& Reinhard Meisterfeld. 2003. Geschichte der romanischen Sprachen, 1: Von den Anfängen bis 1492. Tübingen: Günter Narr Verlag.

Ettmayer, Karl von. 1916. Vulgärlatein. In W. Streitberg (ed.), Grundriß der indogermanischen Sprachen und Altertumskunde, part 2, vol. 1, 231-237. Straßbourg: K. J. Trübner.

Faithfull, R. Glynn. 1953. The concept of "living language" in cinquecento vernacular philology. The Modern Language Review 48. 278-292.

Faithfull, R. Glynn. 1962. Teorie filologiche nell'Italiana del primo Seicento con particolare riferimento alla filologia volgare. Studi di filologia Italiana 20. 147-313.

Ferguson, Charles E. 1959. Diglossia. Word: Journal of the Linguistic Circle of New York 15. 325-340.

Fuchs, August. 1849. Die Romanischen Sprachen in ihrem Verhältnisse zum Lateinischen. Halle: Schmidt.

Geckeler, Horst \& Dietrich Wolf. 2012 [1995]. Einführung in die französische Sprachwissenschaft: Ein Lehr- und Arbeitsbuch, fifth revised and expanded edition. Berlin: Erich Schmidt Verlag.

Haßler, Gerda \& Cordula Neis. 2009. Lexikon sprachtheoretischer Grundbegriffe des 17. und 18. Jahrhunderts. Berlin \& New York: Walter de Gruyter.

Herman, József. 2000. Vulgar Latin (translated by Roger Wright from the French original Le latin vulgaire, 1967). University Park, PA: Pennsylvania State University Press.

Holmes, Urban T. 1928. The vulgar Latin question and the origin of the Romance tongues: Notes for a chapter of the history of Romance philology prior to 1849. Studies in Philology 25(1). 51-61.

Keil, Henrich. 1868. Grammatici Latini. vol. V: Artium scriptores minores. Lipsiae/Leipzig: Teubner.

Kiesler, Reinhard. 2006. Einführung in die Problematik des Vulgärlateins. Tübingen: Niemeyer. 
Kramer, Johannes. 1998. Die Sprachbezeichnungen Latinus und Romanus im Lateinischen und Romanischen. Berlin: Erich Schmidt Verlag.

Kremnitz, Georg. 2004 [1987]. Diglossia - Polyglossia. In Ulrich Ammon (ed.), Sociolinguistics: An international handbook of the science of language and society, 2nd rev. edn, 158-165. Berlin \& New York: Walter de Gruyter.

Laureys, Marc. 2010. A little known plea in defence of Latin: Gabriel Barrius's Pro Lingua Latina. In Trine Arlund Hass \& Johann Ramminger (eds.), Latin and the vernaculars in early modern Europe (Renæssanceforum 6), 23-41. Copenhagen: Forum for Renæssancestudier.

Lloyd, Paul M. 1979. On the definition of "Vulgar Latin": The eternal return. Neuphilologische Mitteilungen 80(2). 110-122.

Lo Piparo, Franco. 1986. Sign and grammar in Dante: A non-modistic language theory. In Paolo Ramat, Hans-J. Niederehe \& Konrad Koerner (eds.), The history of linguistics in Italy, 1-22. Amsterdam: John Benjamins.

Lüdtke, Helmut. 2005. Der Ursprung der Romanischen Sprachen. Eine Geschichte der sprachlichen Kommunkation. Kiel: Westensee Verlag.

Lüdtke, Jens. 2001. Romanische philologie von Dante bis Raynouard: Diakrone romanische Sprachwissenschaft und Sprachgeschichtsschreibung. In G. Holtus, M. Metzeltin \& Chr. Schmitt (eds.), Lexikon der Romanistischen Linguistik, vol. 1(1), 1-35. Tübingen: Niemeyer.

Manczak, Witold. 1995. Le protoroman est-il une langue soeur du latin classique? In Louis Callebat (ed.), Latin vulgaire, latin tardif IV: Actes du 4 e colloque international sur le latin vulgaire et tardif. Caen, 2-5 septembre 1994, 29-34. Hildesheim: Olms-Weidmann.

Marazzini, Claudio. 1993a. Il secondo Cinquecento e il Seicento. Bologna: Società editrice il Mulino.

Marazzini, Claudio. 1993b. La speculazione linguistica nella tradizione italiana: Le teorie. In Luca Serianni \& Pietro Trifone (eds.), Storia della lingua italiana. vol. 1 (1)Luoghi della codificazione, 231-329. Torino/Turin: Einaudi.

Marazzini, Claudio. 1999. Da Dante alla lingua selvaggia: Sette secoli di dibattiti sull'italiano. Roma: Carocci editore.

Mazzocco, Angelo. 1993. Linguistic theories in Dante and the humanists. Studies of language and intellectual history in late medieval and early Renaissance Italy. Leiden, New York \& Cologne: Brill.

Meier, Harri. 1941. Die Entstehung der romanischen Sprachen und Nationen. Frankfurt am Main: Vittorio Klostermann.

Melzi, Robert C. 1966. Castelvetro's annotations to The Inferno. The Hague \& Paris: Mouton.

Müller, Roman. 2001. Sprachbewußtsein und Sprachvariation im lateinischen Schriftum der Antike. Munich: Beck.

Müller-Lancé, Johannes. 2006. Latein für Romanisten: Ein Lehr- und Arbeitsbuch. Tubingen: Günter Narr.

Nauta, Lodi. 2009. In defense of common sense: Lorenzo Valla's humanist critique of scholastic philosophy. Cambridge, MA \& London: Harvard University Press. (Some observations on Valla's views on the history of Latin and its relation to Italian in the final chapter, pp. 277-278.)

Pistolesi, Elena. 2000. Origine del concetto di latino volgare negli studi romanzi: Il caso di Celso Cittadini. In Annick Englebert et al. (eds.), Actes du XXIle Congrès International de Linguistique et Philologie Romanes, vol. 1: L'histoire de la linguistique, médiatrice de théories, 113-120. Tübingen: Niemeyer.

Posner, Rebecca. 1996. The Romance languages. Cambridge: Cambridge University Press. 
Schlemmer, Gerd. 1983a. Die Rolle des germanischen Superstrats in der Geschichte der romanischen Sprachwissenschaft. Hamburg: Helmut Buske Verlag.

Schlemmer, Gerd. 1983b. Einleitung. In G. Schlemmer (ed.), Celso Cittadini. Trattato della vera origine e del processo e nome della nostra lingua scritto in vulgar Sanese. Nachdruck, 9-31. Hamburg: Helmut Buske.

Schöntag, Roger. 2017. Das Verständis von Vulgärlatein in der Renaissance in Rahmen der Diskussion um das vulgare der römischen Antike vor dem Hintergrund der questione della lingua. In Barbara Sonnenhauser, Caroline Trautmann, Holl Daniel \& Patrizia Noel Aziz Hanna (eds.), Synchronie und Diachronie. Diskussionsforum Linguistik/Bavarian Working Papers in Linguistics 6. 111-129. München: Ibykos Verlag.

Schuchardt, Hugo. 1866. Der Vokalismus des Vulgärlateins, vol. 1. Leipzig: B. G. Teubner.

Schunck, Mariella. 2003. Der Sprachwandel im metalinguistischen Diskurs Italians und Frankreichs von der Renaissance zur Aufklärung. Frankfurt am Main: Peter Lang.

Seppänen, Minna. 2014. Defining the art of grammar: Ancient perceptions of $\gamma \rho \alpha \mu \mu \alpha t ı k \eta$ and grammatica. Turku: Painosalama Oy.

Strauss, Franz. 1938. Vulgärlatein und Vulgärsprache im Zusammenhang der Sprachenfrage im 16. Jahrhundert (Frankreich und Italien). Marburg: Michaelis-Braun.

Tavoni, Mirko. 1984. Latino, grammatico, volgare: Storia di una questione umanistica. Padua: Editrice Antenore.

Tavoni, Mirko. 1986. The 15th-century controversy on the language spoken by the ancient Romans: An inquiry into Italian humanist concepts of "Latin", "grammar" and "vernacular". In P. Ramat, H.-J. Niederehe \& K. Koerner (eds.), The history of linguistics in Italy, 23-50. Amsterdam: John Benjamins. Originally published in 1982 in Historiographia linguistica 9(3). 237-264.

Tavoni, Mirko. 1998. Renaissance linguistics: Western Europe. In Guilio Lepschy (ed.), History of linguistics, vol. III: Renaissance and early modern linguistics, 3-108. London \& New York: Longman.

Tavoni, Mirko. 2000. The rediscovery of the classics in the age of humanism. In S. Auroux, K. Koerner, H.-J. Niederehe \& K. Versteegh (eds.), History of the language sciences, vol. 1 (HSK 18:1), 650-656. Berlin \& New York: Mouton de Gruyter.

Thomas, Margaret. 2004. Universal grammar in second language acquisition: A history. London \& New York: Routledge.

Trabalza. 1908. Storia della grammatica italiana. Milan: Ulricho Hoepli.

Valle, Valeria della \& Giuseppe Patota. 2006. L'italiano: Biographia di una lingua. Milan: Sperling \& Kupfer.

Vannini, A. 1920. Notizie intorno alla vita e all' opera di Celso Cittadini. Siena: S. Bernandino.

Vitale, Maurizio. 1955. Sommario elementare di una storia degli studi linguistici Romanzi. In Antonio Viscardi (ed.), Preistoria e storia degli studi Romanzi, 5-169. Milan \& Varese: Cisalpino.

Ward, Michael. 1990. Celso Cittadini and the origin of the vernacular: The convergence of science and subjectivity. In John E. Joseph \& Talbot J. Taylor (eds.), Ideologies of language, 97-111. London \& New York: Routledge.

Ward, Michael. 1992. Celso Cittadini: Linguistic theory in the "Trattato della vera origine" and "Trattato degli articoli”. Canadian Journal of Italian Studies 15 (44).57-69 and 15 (45). 148-159. 
Werner, Edeltrau. 1999. Ansätze einer historisch-vergleichenden Sprachbetrachtung im 17. Jahrhundert in Italien: Celso Cittadini. In G. Haßler \& P. Schmitter (eds.), Sprachdiskussion und Beschreibung von Sprachen im 17. und 18. Jahrhundert, 351-369. Münster: Nodus Publikationen.

Note: This article will be followed by the continuation, "Vulgar Latin as a concept in postRenaissance linguistic thought and modern Romance and Latin linguistics (1600 until the present)," in Journal of Latin Linguistics. 